\title{
THE ROLE OF TRANSIENT RECEPTOR POTENTIAL CHANNELS IN JOINT DISEASES
}

\author{
O. Krupkova ${ }^{1, *}$, J. Zvick$^{1}$ and K. Wuertz-Kozak ${ }^{1,2,3,4}$ \\ ${ }^{1}$ Department of Health Sciences and Technology, Institute for Biomechanics, ETH Zurich, Zurich, Switzerland \\ ${ }^{2}$ Department of Health Sciences, Institute of Sociology of Health and Physical Activity, \\ University of Potsdam, Potsdam, Germany \\ ${ }^{3}$ Schön Clinic Munich Harlaching, Munich, Germany \\ ${ }^{4}$ Spine Centre, Academic Teaching Hospital and Spine Research, Paracelsus Medical University, \\ Salzburg, Austria
}

\begin{abstract}
Transient receptor potential channels (TRP channels) are cation selective transmembrane receptors with diverse structures, activation mechanisms and physiological functions. TRP channels act as cellular sensors for a plethora of stimuli, including temperature, membrane voltage, oxidative stress, mechanical stimuli, $\mathrm{pH}$ and endogenous as well as exogenous ligands, thereby illustrating their versatility. As such, TRP channels regulate various functions in both excitable and non-excitable cells, mainly by mediating $\mathrm{Ca}^{2+}$ homeostasis. Dysregulation of TRP channels is implicated in many pathologies, including cardiovascular diseases, muscular dystrophies and hyperalgesia. However, the importance of TRP channel expression, physiological function and regulation in chondrocytes and intervertebral disc (IVD) cells is largely unexplored. Osteoarthritis (OA) and degenerative disc disease (DDD) are chronic age-related disorders that significantly affect the quality of life by causing pain, activity limitation and disability. Furthermore, currently available therapies cannot effectively slow-down or stop progression of these diseases. Both OA and DDD are characterised by reduced tissue cellularity, enhanced inflammatory responses and molecular, structural and mechanical alterations of the extracellular matrix, hence affecting load distribution and reducing joint flexibility. However, knowledge on how chondrocytes and IVD cells sense their microenvironment and respond to its changes is still limited. In this review, we introduced six families of mammalian TRP channels, their mechanisms of activation as well as activation-driven cellular consequences. We summarised the current knowledge on TRP channel expression and activity in chondrocytes and IVD cells and the significance of TRP channels as therapeutic targets for the treatment of OA and DDD.
\end{abstract}

Keywords: Transient receptor potential channels, degenerative disc disease, osteoarthritis, nociception, mechanosensing, osmosensing, inflammation, calcium.

*Address for correspondence: Olga Krupkova, ETH Zurich, Hoenggerbergring 64, 8093 Zurich, Switzerland. Telephone: +41 446332901 Email: okrupkova@ethz.ch

\section{Introduction}

Transient receptor potential (TRP) channels are cell surface receptors involved in mechanosensing, osmosensing and hyperalgesia. Dysregulation of TRP channels affects mechanical, osmotic and inflammatory sensitivity in various cell types. As evidence suggests that impairment of TRP channels in chondrocytes and intervertebral disc (IVD) cells may contribute to joint degeneration and pain, these channels represent potential therapeutic targets. However, the importance and role of specific TRP channels in chondrocytes and IVD cells is not yet fully explored. Therefore, the aims of this review were (1) to summarise the current knowledge on TRP channel expression and activity in chondrocytes and IVD cells and (2) to discuss the significance of TRP channels as therapeutic targets in the treatment of joint diseases, particularly osteoarthritis (OA) and degenerative disc disease (DDD).

\section{Degenerative joint diseases}

Degenerative joint diseases, such as OA and DDD, are chronic age-related disorders that significantly affect the quality of life.

$\mathrm{OA}$ is the most prevalent form of skeletal disease, representing a leading cause of disability during middle and old age. OA causes degenerative destruction of articular cartilage and joint integrity, being associated with pain (Lawrence et al., 2008). Joint 
structures, such as capsule, synovium and ligaments are innervated by sensory nerves, which can be damaged or sensitised by a variety of chemicals. This results in two types of pain: nociceptive pain, caused by a neural sensitisation due to tissue damage and neuropathic pain, resulting from damaged nerves (Thakur et al., 2014). OA affects around $40 \%$ of people above 70 years of age (Lawrence et al., 2008).

DDD is a progressive loss of function of IVDs and the major contributor to low back pain (LBP), another significant cause of disability in industrialised countries, which affects more than $80 \%$ of people at least once in their life (Pai and Sundaram, 2004; Roberts et al., 2006). Although DDD does not always correlate with the presence and severity of LBP, an IVD-related problem is generally accepted to be the most common cause of LBP (Schwarzer et al., 1995), as degenerated IVDs are frequently invaded by newlyformed nociceptive nerves (Sivan et al., 2014; Urban et al., 2004). Discogenic nociceptive pain is caused by a neuronal sensitisation, due to internal IVD disruption (Roberts et al., 2006), while neuropathic pain arises from neuronal damage and inflammation caused by IVD-related compression of nerve roots (Cramer and Darby, 1997; Ito and Creemers, 2013).

Both OA and DDD are characterised by an age-related reduction in tissue cellularity and molecular, structural and mechanical alterations of the extracellular matrix (ECM). These alterations progressively change the load distribution, reducing the joint flexibility and causing pain (Galbusera et al., 2014; Le Maitre et al., 2007; Neogi, 2013).
Furthermore, both tissues undergo the so-called "inflammaging", i.e. low-grade, aging-associated chronic inflammation (Franceschi and Bonafe, 2003; Mobasheri et al., 2015). As effective treatments are not available, both OA and DDD show high rates of reoccurrence and slow recovery, often becoming chronic (Henschke et al., 2008; Hoy et al., 2010a; Hoy et al., 2010b). With an ageing society and increasing obesity, the incidence and prevalence of OA and DDD is expected to rise, hence further extending the burden on the society and the economy alike (Adams and Roughley, 2006; Galbusera et al., 2014; Peat et al., 2001; Wieser et al., 2011). However, biological mechanisms underlying painful OA and DDD are not sufficiently understood to allow for an accurate therapeutic targeting. Therapies used to manage OA and DDD are, up to the present, limited to pain control, with no agent to date approved for the prevention or treatment of disease progression (Sokolove and Lepus, 2013). However, because of the high potential benefit of such treatments, the research community is actively working on the elucidation of underlying pathobiological mechanisms, as well as on the subsequent identification of novel therapeutic candidates. Over recent years, a new group of possible candidates has emerged, the TRP channels.

\section{Transient receptor potential channels}

TRP channels form a superfamily of cation-selectivetransmembrane receptors with diverse structure, activation mechanisms and physiological functions. More than 50 TRP channels have been identified

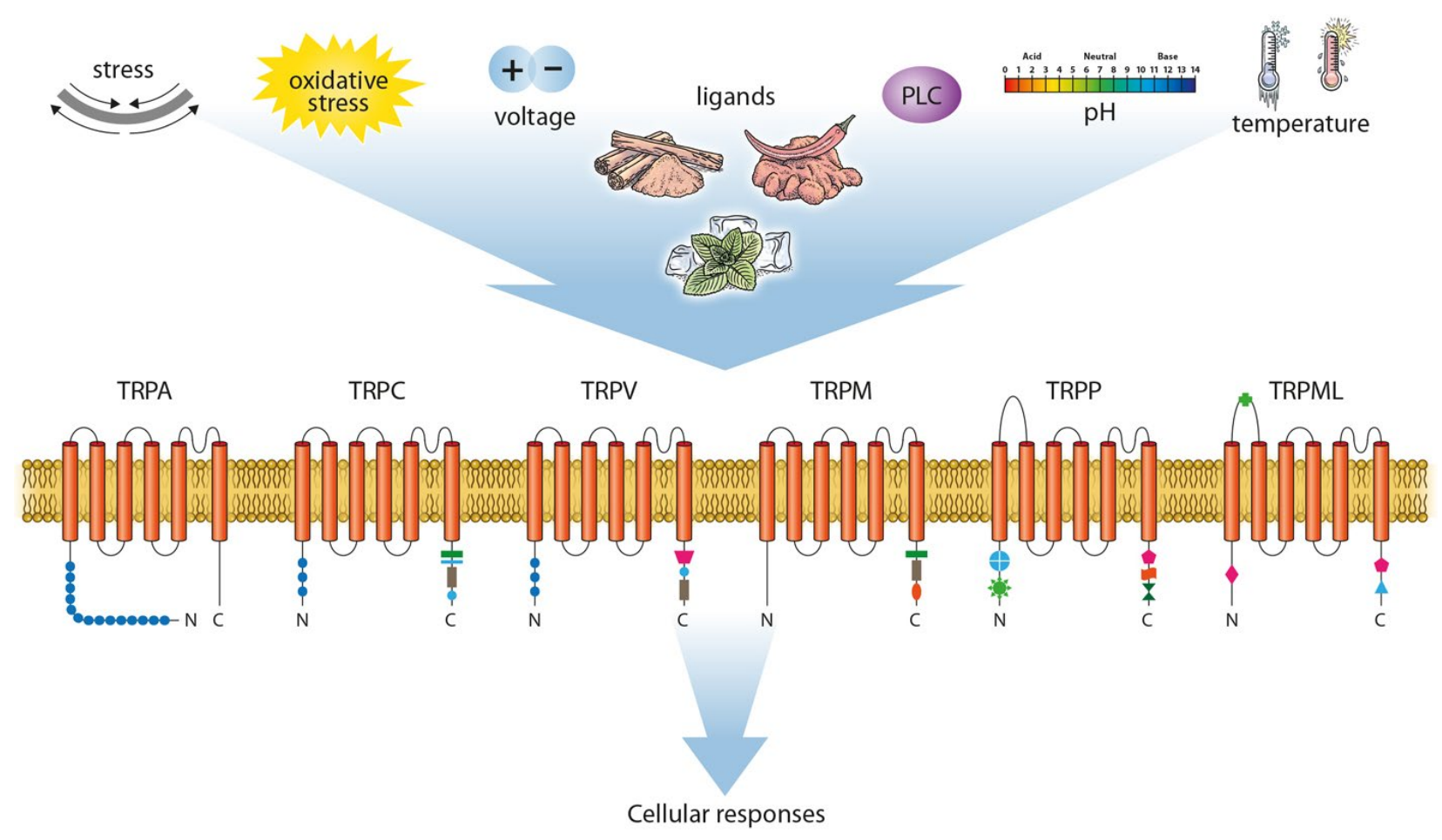

Fig. 1. Families of TRP channels and their activation stimuli. TRP channels act as cellular sensors for a plethora of stimuli, including mechanical and oxidative stress, membrane voltage, endogenous and exogenous ligands, members of phospholipase C (PLC) signalling pathway, $\mathrm{pH}$ and temperature. Activated TRP channels regulate various cellular functions, mainly by mediating $\mathrm{Ca}^{2+}$ homeostasis. 
in many species, with 28 TRP channels discovered in mammals. TRP channels contain six membranespanning domains, intracellular $\mathrm{N}$ - and C-termini and a pore domain between the fifth and the sixth segment, especially permeable for $\mathrm{Ca}^{2+}$ ions (Liu and Montell, 2015). TRP channels mainly function as sensors for various physical and chemical stimuli, such as temperature, $\mathrm{pH}$, plant secondary metabolites, osmolarity and mechanical stress, and regulate cellular responses to these stimuli. As such, they are important for cellular signal transduction, survival and adaptation to environmental changes (Montell et al., 2002; Wu et al., 2010).

Seven families of TRP channels are identified, classifying TRP channels based on their sequence homology and topological differences: TRPA (ankyrin), TRPC (canonical), TRPM (melastatin), TRPV (vanillin), TRPP (polycystin), TRPML (mucolipin) and TRPN (nompC), the latter not being present in mammals. Apart from TRPA, every subfamily has several members (Wu et al., 2010). Most of the TRP channels form tetramers with either homotetrameric or heterotetrameric configurations, with heterotetramers likely assembling within the same subfamily (Gees et al., 2010). Consequently, a large variety of different TRP channel combinations, with unique properties and sensitivity to numerous activation stimuli (Fig. 1), exists (Gees et al., 2010; Strubing et al., 2001).

Associations between TRP channels and human diseases are described. The disorders caused by mutations in TRP genes include focal segmental glomerulosclerosis (TRPC6), autosomal recessive congenital stationary night blindness (TRPM1), adult polycystic kidney disease (TRPP1), mucolipidosis type IV (TRPML1) and skeletal disorders, such as brachyolmia or metatropic dysplasia (TRPV4). Evidence suggests that hereditary and acquired abnormalities in TRP channel function are implicated in numerous other diseases, among which cardiovascular diseases, muscle dystrophies and pain-related pathologies are the most prominent (Everett, 2011; Nilius and Owsianik, 2010). However, the exact mechanisms underlying TRP channel involvement in human diseases are largely unknown. This uncertainty is partially related to the fact that TRP channels are commonly activated by multimodal mechanisms (Rohacs, 2013; Venkatachalam and Montell, 2007; Zheng, 2013). As most of the known TRP agonists and antagonists simultaneously interact with multiple TRP channels (Ramsey et al., 2006), studying their biological functions is challenging. Interestingly, TRP channels do not always locate to the plasma membrane as functional channels, but may have other intracellular roles yet to be fully identified.

Studies performed in TRP-deficient mice reveal important information on the role of TRP channels in mammalian physiology (Desai and Clapham, 2005). TRP channel knockout (KO) or knockdown (KD) often cause impairment in sensing of innocuous and noxious environmental stimuli, such as heat, cold or taste. Interestingly, most KO phenotypes are quite moderate, suggesting that TRP isoforms can compensate for the lack of a specific channel (Birnbaumer, 2009). The phenotypes of TRP-deficient mice created up to date are summarised in Table $\mathbf{1} \mathbf{a}, \mathbf{b}$ and described in more detail in the publications by David E. Clapham and colleagues (Desai and Clapham, 2005; Wu et al., 2010). Although rodent studies provide valuable data, simple translation of this knowledge to human medicine is not always possible due to the different anatomy and physiology of rodents. In addition, tools to study TRP channel function in vivo are largely unavailable.

In vitro and in vivo studies reveal that TRP channels are involved in modulation of cellular homeostasis, mainly by regulating $\mathrm{Ca}^{2+}$ influx in a variety of excitable and non-excitable cell types (Gees et al., 2010; Nilius and Owsianik, 2011). TRP channels are not only located in the plasma membrane, but also in intracellular organelles, such as sarco/endoplasmic reticulum and endosomes, lysosomes or autophagosomes (Grimm et al., 2012). Therefore, TRP channels can function as (1) $\mathrm{Ca}^{2+}$ entry sites on the plasma membrane, (2) electrogenic mediators changing the membrane polarisation or (3) $\mathrm{Ca}^{2+}$ release channels in intracellular organelles (Gees et al., 2010). TRP channels differ in their pore size and permeability for $\mathrm{Ca}^{2+}$, depending on their pore structure. Although most TRP channels are $\mathrm{Ca}^{2+}$ permeable, their selectivity varies among the different members, with $\mathrm{P}_{\mathrm{Ca}} / \mathrm{P}_{\mathrm{Na}}$ ratios ranging from $<1$ for TRPM1 to $>100$ for TRPV5 and TRPV6 (Gees et al., 2010).

TRP channels activity is modulated by diverse extracellular and intracellular stimuli sensed through a single or multistep process. Assignment of a TRP channel to a subfamily does not always determine its mode of activation, as different TRP channels can be regulated through the same stimulus (Montell et al., 2002; Zheng, 2013). Various agonists and antagonists of mammalian TRP channels have been reported (Numata et al., 2011). In addition, TRP channels can be modulated by intracellular phospholipase C (PLC) signalling. Apart from direct activation and inhibition, the function of TRP channels is also regulated on the gene expression level and through their membrane trafficking (Bezzerides et al., 2004; Numata et al., 2011; Schmidt et al., 2009). Multiple mechanisms of TRP channel modulation were proposed in in vitro studies; however, it is still unclear how these data correspond to an in vivo situation.

\section{Emerging role of TRP channels in joint diseases}

Several TRP channels are expressed in joints, but their potential biological function and therapeutic relevance is not yet fully understood. The presence and severity of pain in OA and DDD is associated with cellular decline, ECM degradation and activity of inflammatory cytokines (Aoki et al., 2014; Grassel, 2014; Halliday et al., 1998; Pecchi et al., 2014). It has 
Table 1a. Phenotypes of TRP-deficient mice. GABA = gamma-aminobutyric acid, OA = osteoarthritis, DRG $=$ dorsal root ganglion, IFN $\gamma=$ interferon gamma, IL-12 = interleukin 12, ROS = reactive oxygen species, CA1 = carbonic anhydrase 1 .

\begin{tabular}{|c|c|c|}
\hline $\begin{array}{c}\text { TRP } \\
\text { channel }\end{array}$ & Phenotype & References \\
\hline TRPA1 $^{-/-}$ & $\begin{array}{l}\text { impaired responses to noxious cold and oxidative stress } \\
\text {. } \\
\text { reduced nociception hypersensitivity in arthritic joints } \\
\text { chemical injury } \\
\text { checreased basal levels of pro-inflammatory mediators }\end{array}$ & $\begin{array}{l}\text { Bessac et al., 2008; Horvath et } \\
\text { al., 2016; Karashima et al., 2009; } \\
\text { Kun et al., 2014; Kwan et al., } \\
\text { 2006; Okada et al., } 2014\end{array}$ \\
\hline TRPC1 $^{-/-}$ & $\begin{array}{l}\text { - } \begin{array}{l}\text { decreased endothelial transmigration of neutrophils } \\
\text { decreased inflammatory response and ineffective bacterial clearance } \\
\text { no pulmonary hypertension response to chronic hypoxia and } \\
\text { reduced vascular muscularisation }\end{array} \\
\end{array}$ & $\begin{array}{l}\text { Lindemann et al., 2015; Malc- } \\
\text { zyk et al., 2013; Zhou et al., } 2015\end{array}$ \\
\hline TRPC2 $^{-/-}$ & $\begin{array}{l}\text { altered responses to pheromones } \\
\text { TRPC2 is not functionally expressed in humans }\end{array}$ & $\begin{array}{l}\text { Beny and Kimchi, 2016; Desai } \\
\text { and Clapham, 2005; Leypold } \\
\text { et al., 2002; Stowers et al., 2002; } \\
\text { Wu et al., } 2014\end{array}$ \\
\hline TRPC3 $^{-/-}$ & $\begin{array}{l}\text {. } \text { defective normal functioning of the hind paws } \\
\text { no effect on agonist-mediated vasoconstriction or nonspecific } \\
\text { depolarisation } \\
\text { decreased behavioral manifestations of seizures }\end{array}$ & $\begin{array}{l}\text { Hartmann et al., 2008; } \\
\text { Kochukov et al., 2013; Phelan } \\
\text { et al., } 2017\end{array}$ \\
\hline TRPC4 $^{-/-}$ & $\begin{array}{l}\text {. } \begin{array}{l}\text { impaired endothelium-dependent relaxation of blood vessels } \\
\text { changes in microvascular permeability and GABA release from } \\
\text { thalamic interneurons }\end{array} \\
\end{array}$ & $\begin{array}{l}\text { Freichel et al., 2004; Tiruppathi } \\
\text { et al., 2006; Tsvilovskyy et al., } \\
2009\end{array}$ \\
\hline TRPC $^{-/-}$ & $\begin{array}{l}\text {. changes in adaptation to innocuous cold in the peripheral nervous } \\
\text { system } \\
\text { severe daily blood pressure fluctuation, impaired blood pressure } \\
\text { stability } \\
\text { reduced seizures and minimal seizure-induced neuronal cell death } \\
\text { in hippocampus }\end{array}$ & $\begin{array}{l}\text { Lau et al., 2016; Phelan et al., } \\
\text { 2013; Zimmermann et al., } 2011\end{array}$ \\
\hline TRPC6 $^{-/-}$ & $\begin{array}{ll}\text { increased smooth muscle tone } \\
\text {. } & \text { reduced albuminuria after } 28 \mathrm{~d} \text { infusion of angiotensin II }\end{array}$ & $\begin{array}{l}\text { Dietrich et al., 2003; Eckel et } \\
\text { al., } 2011\end{array}$ \\
\hline TRPC7 $^{-/-}$ & $\begin{array}{l}\text { - reduction in pilocarpine-induced increase in gamma waves } \\
\text { preceding seizures }\end{array}$ & Phelan et al., 2014 \\
\hline TRPV1 $^{-/-}$ & \begin{tabular}{|l}
. \\
loss of function in DRG \\
altered mechanical and osmotic function in urinary bladder \\
impaired nociception, pain and fever responses \\
attenuated ear swelling and expression of neurotrophin mRNA after \\
painting ears with $5 \%$ formalin
\end{tabular} & $\begin{array}{l}\text { Birder et al., 2002; Caterina } \\
\text { et al., 2000; Davis et al., 2000; } \\
\text { Fang et al., 2014; Iida et al., } \\
\text { 2005; Ishikura et al., 2015; } \\
\text { Wakabayashi et al., 2017 }\end{array}$ \\
\hline TRPV2 $^{-/-}$ & $\begin{array}{l}\text {. } \\
\text { increased perinatal lethality } \\
\text { when fed with high fat diet) } \\
\text { improved cardiac recovery after permanent left anterior descending } \\
\text { artery occlusion } \\
\text { heart specific KO: decreased induction of thermogenic genes in } \\
\text { brown adipocytes and cold intolerance }\end{array}$ & $\begin{array}{l}\text { Entin-Meer et al., 2017; } \\
\text { Katanosaka et al., 2014; Park et } \\
\text { al., 2011; Sun et al., } 2016\end{array}$ \\
\hline TRPV3 $^{-/-}$ & $\begin{array}{l}\text {. } \text { deficits in responses to innocuous and noxious heat } \\
\text {. } \text { delayed oral wound closure }\end{array}$ & $\begin{array}{l}\text { Aijima et al., 2015; Moqrich et } \\
\text { al., } 2005\end{array}$ \\
\hline TRPV4 $^{-/-}$ & $\begin{array}{ll}\text {. } & \text { impaired osmotic regulation and pressure sensation } \\
\text {. } & \text { impreased knee OA scores } \\
\text {. } & \text { reduced spontaneous cage activity } \\
\text {. } & \text { increasing weight gain and adiposity } \\
\text {. } & \text { no incrurbed signaling during noxious stimulation of the bladder } \\
\text {. } & \text { lower mean arterial pressure baseline - potential involvement in } \\
\text { angiotensin II-induced endothelial dysfunction } \\
\text { impaired thermotaxis of sperm } \\
\text { cartilage specific KO: reduced age-related OA }\end{array}$ & $\begin{array}{l}\text { Hamano et al., 2016; Janssen } \\
\text { et al., 2016; Liedtke and } \\
\text { Friedman, 2003; Mizuno et } \\
\text { al., 2003; Nishijima et al., 2014; } \\
\text { O'Conor et al., 2013; O'Conor } \\
\text { et al., 2016; Suzuki et al., } 2003\end{array}$ \\
\hline
\end{tabular}


Table 1b. Phenotypes of TRP-deficient mice. GABA = gamma-aminobutyric acid, OA = osteoarthritis, DRG $=$ dorsal root ganglion, IFN $\gamma=$ interferon gamma, IL-12 = interleukin $12, \mathrm{ROS}=$ reactive oxygen species, CA1 = carbonic anhydrase 1 .

\begin{tabular}{|c|c|c|}
\hline $\begin{array}{c}\text { TRP } \\
\text { channel }\end{array}$ & Phenotype & References \\
\hline TRPV5 ${ }^{-/-}$ & $\begin{array}{ll}\cdot & \text { reduced bone thickness and renal calcium reabsorption } \\
\text {. } & \text { increased intestinal calcium hyperabsorption } \\
\text {. } & \text { hypercalciuria } \\
\text { increased age-related changes in trabecular and cortical bone mass }\end{array}$ & $\begin{array}{l}\text { Hoenderop et al., 2003; } \\
\text { Renkema et al., 2005; van der } \\
\text { Eerden } \text { et al., } 2016\end{array}$ \\
\hline TRPV6 $^{-/-}$ & $\begin{array}{ll}\cdot & \text { destruction of bone microarchitecture } \\
\cdot & \text { decreased foetal blood } \mathrm{Ca}^{2+} \text { level } \\
\cdot & \mathrm{Ca}^{2+} \text { deficiency and abnormal development } \\
\text {. } & \text { hypofertility in males }\end{array}$ & $\begin{array}{l}\text { Bianco et al., 2007; Chen et } \\
\text { al., 2014; Suzuki et al., 2008; } \\
\text { Weissgerber et al., } 2012\end{array}$ \\
\hline TRPM1 $^{--}$ & $\begin{array}{l}\text { no b-wave in bipolar cells } \\
\text { no accumulation of melanoma-associated retinopathy autoantibodies } \\
\text { on intracellular epitope of TRPM1 }\end{array}$ & $\begin{array}{l}\text { Morgans et al., 2009; Shen et al., } \\
\text { 2009; Ueno et al., 2013; Xiong } \\
\text { et al., } 2013\end{array}$ \\
\hline TRPM2 $^{--}$ & $\begin{array}{l}\text { reduced sensation of non-noxious warm temperatures } \\
\text { higher mortality and increased bacterial burdens already at early } \\
\text { stage of listeria infection, and reduced production of IFN- } \gamma \text { and } \\
\text { IL-12 } \\
\text { delayed increase in zinc concentration, ROS generation, CA1 } \\
\text { pyramidal neuronal death and post-ischemic memory impairment } \\
\text { after transient ischemic brain injury } \\
\text { anti-allodynic effect in inflammatory and neuropathic pain } \\
\text { reduced salivary gland function after radiotherapy }\end{array}$ & $\begin{array}{l}\text { Knowles et al., 2011; Liu et al., } \\
\text { 2013; So et al., 2015; Tan and } \\
\text { McNaughton, 2016; Ye et al., } \\
2014\end{array}$ \\
\hline TRPM3 $^{--}$ & $\begin{array}{l}\text { deficits in noxious heat avoidance } \\
\text { development of inflammatory heat hyperalgesia }\end{array}$ & Vriens et al., 2011 \\
\hline TRPM4 $^{-/-}$ & $\begin{array}{l}\text { impaired chemokine-dependent dendritic cell migration } \\
\text { shortened ventricular action potential } \\
\text { increased B-adrenergic inotropy of the heart muscle }\end{array}$ & $\begin{array}{l}\text { Barbet et al., 2008; Demion et al., } \\
\text { 2014; Mathar et al., } 2014\end{array}$ \\
\hline TRPM5 $^{--}$ & $\begin{array}{l}\text { impaired response to sweet, umami and bitter tastes } \\
\text { improved glucose tolerance }\end{array}$ & $\begin{array}{l}\text { Zhang et al., 2003; Larsson et } \\
\text { al., } 2015\end{array}$ \\
\hline TRPM6 $^{--}$ & - homozygous deficiency is in most cases lethal & $\begin{array}{l}\text { Walder et al., } 2009 \text {; } \\
\text { Woudenberg-Vrenken et al., } \\
2011\end{array}$ \\
\hline TRPM7 $7^{-/-}$ & $\begin{array}{l}\text { decreased hyperplasia associated with increased adult cardiomyocyte } \\
\text { size }\end{array}$ & Sah et al., 2013 \\
\hline TRPM8 $^{-/-}$ & $\begin{array}{l}\text { absence of jumping after icilin injection } \\
\text { diminished cold response } \\
\text { decreased discrimination between cold and warm surfaces }\end{array}$ & $\begin{array}{l}\text { Bautista et al., 2007; Colburn et } \\
\text { al., 2007; Dhaka et al., } 2007\end{array}$ \\
\hline TRPP1 $^{--}$ & $\begin{array}{ll} & \text { abnormal male reproductive tract } \\
\text { bone specific KO: reduced long bone weight and length }\end{array}$ & $\begin{array}{l}\text { Boulter et al., 2001; Li et al., } \\
\text { 2017; Nie and Arend, } 2013\end{array}$ \\
\hline TRPP2 $^{-/-}$ & $\begin{array}{l}\text { cysts in kidney and pancreas } \\
\text { defects in cardiac septum } \\
\text { focal haemorrhage } \\
\text { total body edema } \\
\text { male reproductive tract defects } \\
\text { embryonic lethality }\end{array}$ & $\begin{array}{l}\text { Boulter et al., 2001; Kim et al., } \\
\text { 2009; Nie and Arend, 2014; Wu } \\
\text { et al., } 1998\end{array}$ \\
\hline TRPML1 $^{-/-}$ & $\begin{array}{l}\text { dense inclusion bodies in all cell types in brain } \\
\text { glial cell activation and reduced myelination } \\
\text { retinal degeneration } \\
\text { neurological defects } \\
\text { impairment in basal and histamine-stimulated gastric acid secretion } \\
\text { and reduced levels of gastric proton pump } \\
\text { enlarged parietal cells, abnormal lysosomes and canalicular } \\
\text { membrane }\end{array}$ & $\begin{array}{l}\text { Chandra et al., 2011; Micsenyi } \\
\text { et al., 2009; Venugopal et al., } \\
2007\end{array}$ \\
\hline TRPML2 $^{-/-}$ & - $\quad$ reduced secretion of CCL2 & (Sun et al., 2015) \\
\hline TRPML3 $^{-/-}$ & . unknown & \\
\hline
\end{tabular}


been shown that ECM changes and hyperalgesia may correlate with dysregulation of TRP channels, suggesting that TRP channels are involved in sensing and regulating inflammation, mechanical and osmotic stress as well as pain in joints (Gavenis et al., 2009). Current knowledge on TRP channel expression and activity in nociceptors, chondrocytes and IVD cells is summarised below and in Fig. 2.

\section{TRP channels in joint pain signalling and inflammation}

Dysregulated sensory responses to noxious, irritant and inflammatory stimuli underlie chronic diseases, including OA and DDD. Interestingly, in both OA and DDD, the severity of pain does not always correlate with macroscopic structural evidence of joint/IVD damage. This is explained by the fact that pain perception comprises a complex series of neurophysiologic events involving stimulation, tissue response, transmission of pain signal and subsequent modulation of these at both peripheral and central levels (Ito and Creemers, 2013; Schaible, 2012).

Inflammatory cytokines are important regulators of these pain mechanisms and their presence is associated with inflammatory pain arising from articular joints and IVDs (Ito and Creemers, 2013; Wuertz et al., 2012; Zhang et al., 2013). Interleukin-1 beta (IL-1 $\beta$ ) and tumour necrosis factor alpha (TNF- $\alpha$ ) contribute to disease progression and pain, by acting directly not only as nociceptive triggers, but also by inducing generation of other potentially nociceptive molecules, including nitric oxide and prostaglandin E (Liu et al., 2016; Risbud and Shapiro, 2014). IL$1 \beta$ and TNF- $\alpha$ are secreted by cells of the immune system, such as macrophages, and by a variety of other cells types, including chondrocytes, annulus fibrosus (AF) and nucleus pulposus (NP) cells, regulating host responses to stress, inflammation, infection or trauma (Berenbaum, 2013; Johnson et al., 2015; Oda et al., 2004; Vo et al., 2016). IL-1 $\beta$ and TNF- $\alpha$ are known to activate nuclear factor $\kappa \mathrm{B}$ (NF$\kappa B)$, c-Jun N-terminal protein kinase (JNK) and/ or p38 mitogen-activated protein kinase (MAPK) (Hoyland et al., 2008; McNulty et al., 2009; Vo et al., 2013; Wang et al., 2015; Wilusz et al., 2008). Activation of these kinases results in the transcription of inflammatory and catabolic genes, such as interleukins, collagenases [matrix metalloproteinases (MMPs)], aggrecanases (ADAMTS) and molecules that promote pain, including cyclooxygenase 2 (COX$2)$, nerve growth factor (NGF) and inducible nitric oxide synthase (iNOS) (Johnson et al., 2015; Ricciotti and FitzGerald, 2011; Vo et al., 2013; Wuertz and Haglund, 2013). In addition to the catabolic and proinflammatory effects, IL- $1 \beta$ and TNF- $\alpha$ can influence cell senescence, autophagy and expression of genes involved in chondrocyte proliferation (Goldring and Otero, 2011; Risbud and Shapiro, 2014). As such, IL$1 \beta$ and TNF- $\alpha$ play a significant role in cartilage and IVD homeostasis, but the mechanisms involved in transduction and modulation of their signal are not yet well-understood (Freemont et al., 1997; Kepler et al., 2013; Sokolove and Lepus, 2013; Zhang and An, 2007). The expression and activity of TRP channels is found altered in in vitro and in vivo studies on painful joint disorders, suggesting that signals provided by pro-inflammatory cytokines may be transduced and modulated through TRP channels. Current results and hypotheses on how inflammation can regulate or be regulated by TRP channels are given below and in Fig. 2.

\section{TRPA}

TRPA1, currently the only known member of the TRPA family, is possibly involved in the development of joint-associated chronic pain and mechanical hyperalgesia. TRPA1 is widely expressed in sensory neurons, such as those in nociceptive dorsal root ganglia (DRG), and in non-neuronal cells including epithelial cells, keratinocytes and chondrocytes (Atoyan et al., 2009; Boesmans et al., 2011; Buch et al., 2013; Nummenmaa et al., 2016). Both neuronal and non-neuronal TRPA1 can be involved in the development of pain.

TRPA1 mediates mechanical hyperalgesia upon plantar injection of TNF- $\alpha$ in mice (Fernandes et al., 2011) and mechanical hyperalgesia is reduced upon the application of the TRPA1 antagonist HC-030031 (Eid et al., 2008b). In addition, hyperalgesia is also attenuated in the TRPA ${ }^{-/}$mouse model of chronic arthritis, suggesting the involvement of neuronal TRPA1 in OA pain (Eid et al., 2008; Horváth et al., 2016). In neurons, TRPA1 often co-localises with TRPV1, a TRP channel contributing to nerve sensitisation and hyperalgesia (Andrei et al., 2016; Brain, 2011), and both TRPA1 and TRPV1 are required for bradykinin-induced thermal hyperalgesia (Bautista et al., 2006). Therefore, TRPA1 and TRPV1, highlighted in more detail in the next subchapter, seem to integrate noxious stimuli and regulate responses to pain and neurogenic inflammation (Fernandes et al., 2012). TRPA1 is also expressed in human OA chondrocytes and its expression can be upregulated by pro-inflammatory cytokines (Bautista et al., 2006; Hatano et al., 2012a; Horváth et al., 2016). Interestingly, we have recently detected similar response patterns in human IVD cells (Zvick, 2017). In IL-1 $\beta$-stimulated OA chondrocytes, the application of a TRPA1 antagonist reduced the expression of inflammatory and catabolic genes and proteins, indicating that TRPA1 contributes to transmission of chondrocyte inflammation (Nummenmaa et al., 2016). Mechanisms by which inflammatory mediators influence the activity of TRPA1 gene were investigated in synoviocytes. Inflammation-induced TRPA1 gene expression in synoviocytes increases via $\mathrm{NF}-\kappa \mathrm{B}$ signalling and activation of the transcription factor hypoxia-inducible factor- $1 \alpha$ (HIF1 $\alpha)$, which binds to specific regions in the TRPA1 gene (Hatano et al., 2012b). TRPA1 expression and activity in sensory neurons and non-neuronal cells is not only modulated by pro-inflammatory cytokines, but also 
by neuropeptides and ROS (Bautista et al., 2006; Hatano et al., 2012a; Nilius et al., 2012; Nummenmaa et al., 2016; Sullivan et al., 2015; Yu and Ouyang, 2009), all of which are commonly elevated in OA synovial fluid and degenerated IVDs (Bandell et al., 2004; Feng et al., 2017; Nummenmaa et al., 2016). These data suggest that blockage of TRPA1 may be beneficial in reducing chronic pain and inflammation associated with joint pathologies.

\section{TRPV}

TRPV1, also known as the capsaicin receptor, is one of the six members of the TRPV family (TRPV1, TRPV2,
TRPV3, TRPV4, TRPV5 and TRPV6). TRPV1 is mainly expressed in sensory neurons and trigeminal ganglions, but also in multiple non-neuronal cell types. As TRPV1 protein expression is increased in synovium of OA knee joints in a rat OA model and as mechanical hyperalgesia is reversed upon TRPV1 blockage (Kelly et al., 2015), TRPV1 is possibly involved in painful OA. The association of TRPV1 with OA is also shown in a murine model, where the upregulation of TRPV1 in sensory neurons - through complete Freund's adjuvant (CFA) - contributes to nociception and severity of knee OA (Chen et al., 2009). The authors show that TRPV1 is co-expressed
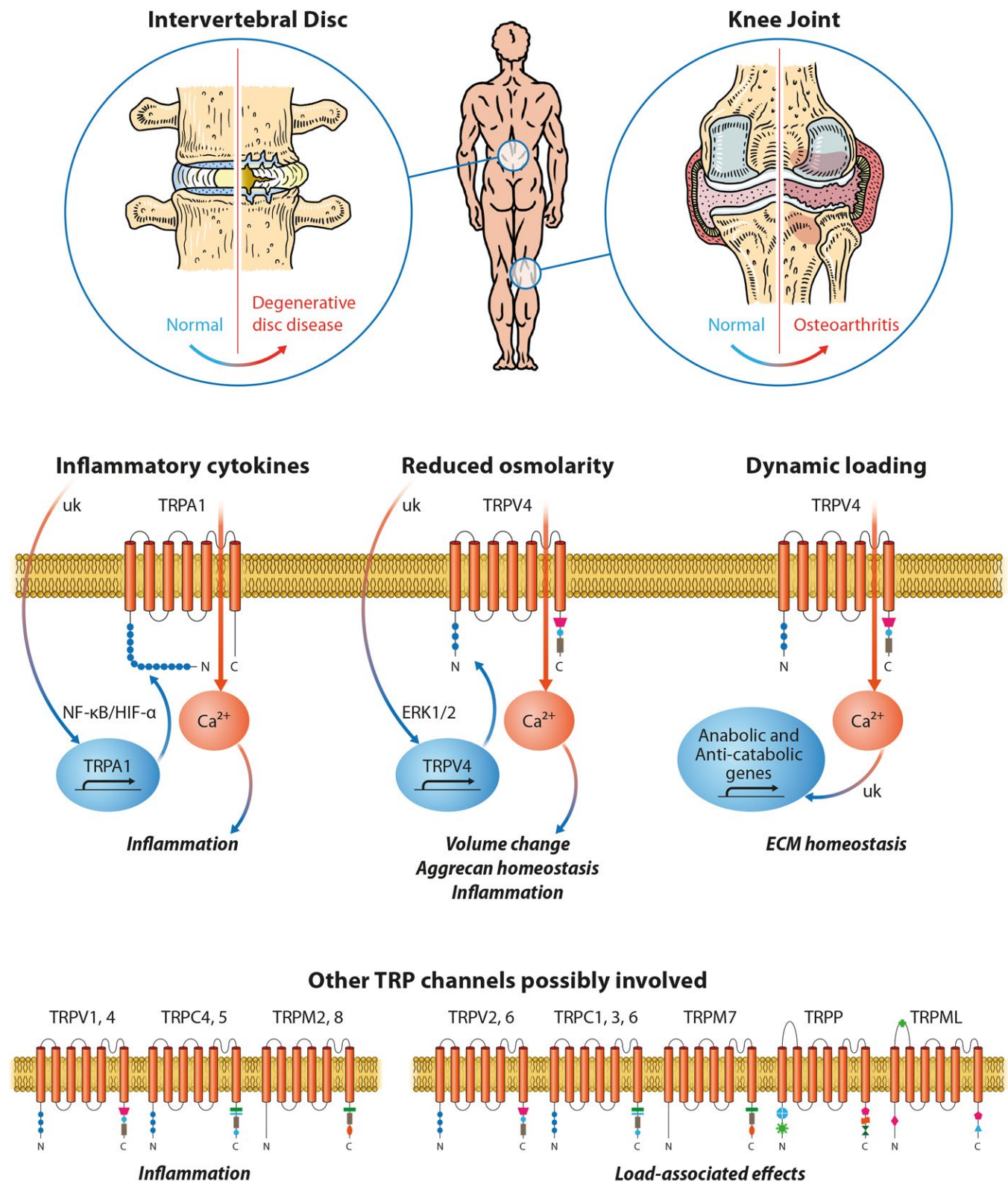

Fig. 2. Function of TRP channels in joint diseases. The gene expression of TRPA1 in cartilaginous tissues can be stimulated by inflammatory cytokines and regulated by NF- $\kappa B$ and HIF- $\alpha$. Active TRPA1 further promote inflammatory responses. The expression of TRPV4 is influenced by osmolarity and regulated by ERK1/2. Active TRPV4 is implicated in cellular volume change, aggrecan homeostasis and inflammatory responses. $\mathrm{Ca}^{2+}$ influx through TRPV4 can be directly stimulated by physiological loading, promoting expression of anabolic and anti-catabolic genes. Evidence suggests that other TRP channels also contribute to inflammation and load-induced effects in degenerative disc disease and osteoarthritis, but their involvement is not completely understood. $\mathrm{uk}=$ exact mechanism unknown. 
with p-ERK, indicating the involvement of ERK in TRPV1-mediated effects. Furthermore, activation of ERK in sensory neurons ofTRPV1 ${ }^{-/}$mice is reduced compared to wild-type (WT) mice and these changes correlate with changes in pain behaviour and joint histopathology (Chen et al., 2009). In the spine, TRPV1 is localised in dorsal root ganglion (DRG) neurons that innervate IVDs. TRPV1 expression and activity in DRGs increases after inflammatory stimulation, possibly causing chronic inflammatory pain, including thermal hyperalgesia and mechanical allodynia in rats (Yu et al., 2008). It is shown that not only the plasma membrane, but also the endoplasmic reticulum (ER) of DRG neurons contains TRPV1, which is involved in $\mathrm{Ca}^{2+}$ depletion from ER and ER stress response (Gallego-Sandin et al., 2009). ER TRPV1 may also serve as pool for rapid TRPV1 mobilisation to the plasma membrane, since ERlocated TRPV1 channels are quickly inserted into the plasma membrane in reaction to neurotrophins, such as NGF, providing an explanation for inflammatory sensitisation and hyperalgesia (Stein et al., 2006; Zhang et al., 2005). In addition, protein kinase C (PKC) signalling is involved in the exocytosis of TRPV1 to the cell surface (Morenilla-Palao et al., 2004). TRPV1 is also expressed in chondrocytes (Gavenis et al., 2009) and IVD cells (unpublished data), but its exact function and mechanisms of regulation in these cell types are yet unknown. TRPV1 is activated by acidic $\mathrm{pH}$ (Dhaka et al., 2009), which is an important factor in chondrocyte and IVD homeostasis. Lactic acid accumulates in degenerative joints and IVDs as a result of impaired fluid transport (Roberts et al., 2006; Urban et al., 2004), altering the cellular repair capacity and promoting pain (Le Maitre et al., 2007). As a putative sensor for acidic $\mathrm{pH}$, over-stimulated or up-regulated TRPV1 can be possibly involved in the responses of chondrocytes and IVD cells to acidity. Therefore, TRPV1 inhibition or desensitisation may be beneficial against $\mathrm{pH}$-induced hyperalgesia.

Evidence suggests that another member of the TRPV family, namely TRPV4, is functionally expressed in bovine IVD cells stimulated by proinflammatory cytokines (Walter et al., 2016). TRPV4 could also be involved in mediating thermal hyperalgesia and inflammatory swelling in inflamed joints (Keeble et al., 2005). Apart from hyperalgesia, TRPV4 regulates transduction of mechanical and osmotic signals activated by load and swelling in chondrocytes and IVD cells, as outlined in detail below (Guler et al., 2002; Kohler and Hoyer, 2007; Phan et al., 2009; Strotmann et al., 2000b; Todaka et al., 2004).

\section{TRPC}

Several members of the TRPC family, classified into TRPC1, TRPC2, TRPC3/6/7 and TRPC4/5 subfamilies, may be of relevance in pain signalling and inflammation in joints. The TRPC family includes non-selective $\mathrm{Ca}^{2+}$ permeable channels that share the potentiated stimulation by G-protein coupled receptor (GPCR) and phospholipase C (PLC) (Freichel et al., 2004; Vazquez et al., 2004). Most TRPC channels are widely expressed and a given cell type usually contains more than one TRPC isoform (Gees et al., 2010).

TRPC4 is expressed in various cells of the nervous system, as well as in endothelial cells, where it is involved in regulation of blood vessel tone (Freichel et al., 2004; Qian et al., 2002). Moreover, it contributes to axonal regeneration after DRG nerve injury. Suppression of TRPC4 inhibits neuronal growth, while overexpression of TRPC4 rescues it (Wu et al., 2008). Although axonal growth is favourable in neuronal regeneration, it is not desired in aneural cartilage and IVD tissue, where enhanced neuronal growth, possibly because of dysregulation of TRPC4 expression and activity, may aggravate pain. Interestingly, the activation of TRPC5 in inflamed joints may also be associated with an endogenous anti-inflammatory/analgesic pathway. In mice, genetic deletion or pharmacological blockage of TRPC5 results in enhanced joint inflammation and hyperalgesia (Alawi et al., 2017). More studies are needed to understand whether activation of TRPC4 and TRPC 5 can be beneficial in the treatment of joint pain. Apart from inflammation and pain, TRPC channels are also involved in tissue mechanosensing, described in next subchapter.

\section{TRPM}

Members of TRPM family, grouped into TRPM1/3, TRPM2, TRPM4/5, TRPM6/7 and TRPM8 subfamilies, play an important role in various cellular processes, including cell proliferation, cell survival and sensing of stress. TRPM2 can be activated by reactive oxygen species (ROS), especially by $\mathrm{H}_{2} \mathrm{O}_{2}$, functioning as a sensor for oxidative stress (Fonfria et al., 2004). A typical microenvironment of chondrocytes and IVD cells is hypoxic, but concentration of ROS in cartilage and IVD increases with aging and degeneration (Feng et al., 2017). However, the sensors for ROS in these cells remain unknown. If TRPM2 would function as a receptor for ROS in chondrocytes and IVD cells, targeting its expression and activity could reduce sensitivity of these cells to oxidative stress-induced aging and degeneration. TRPM8 is widely expressed, most abundantly in a subset of pain and temperature sensitive neurons, involved in hyperalgesia and nociception (Behrendt et al., 2004). Neuronal TRPM8 could possibly also transmit pain in joint disorders, but evidence is lacking.

\section{TRP channels in join mechanosensing and osmosensing}

Physiological mechanical load and balanced osmolarity are crucial for the normal function of chondrocytes and IVD cells. Joints and IVDs are under the influence of complex mechanical loads, with every structural part taking over different loading patterns. Their ability to withstand the applied loads gradually decreases throughout the 
individual's lifetime, leading to the development of pain (Inoue and Espinoza Orias, 2011; Thakur et al., 2014). However, the molecular basis of how these tissues respond to their osmotic and mechanical environments is not fully understood.

Articular cartilage and IVDs are complex structures, composed of water (60-80 \%), ECM (20$40 \%$ ) and a small number of cells (1-3\%) (Sophia Fox et al., 2009; Urban and Roberts, 2003). Both articular cartilage and IVDs contain a collagen fibre network placed under tension by the swelling pressure of proteoglycans dispersed within these tissues. Collagen type I provides tensile resistance to the applied loads, whereas collagen type II supports the maintenance of an adequate osmotic pressure induced by proteoglycans (Cramer and Darby, 1997; Le Maitre et al., 2007; Maroudas, 1976; Sophia Fox et al., 2009; Urban and Roberts, 2003). Proteoglycans possess negative fixed charges electrically balanced by positive cations, mainly potassium and sodium, located in the interstitial fluid. Upon application of a load, the tissue loses water, while removal of the applied load causes rapid rehydration due to the presence of positively charged ions, creating osmotic gradients (Cramer and Darby, 1997; Galbusera et al., 2014; Han et al., 2011; Urban and Roberts, 2003). Thus, the presence of proteoglycans provides cartilage and IVDs with the ability to resist the compressive loads.

The complex interplay of magnitude, duration and frequency of the mechanical loads determines subsequent osmolarity-mediated biological alterations in articular cartilage and IVD tissue. Physiological mechanical loading can restore the biochemical properties of both tissues, while underloading and overloading reduce tissue function (Gawri et al., 2014; Setton and Chen, 2006; Verteramo and Seedhom, 2007; Wang et al., 2013). ECM turnover is regulated by MMPs and ADAMTS and it is affected by age and degeneration, as the ability of cartilaginous tissues to maintain the ECM declines when both factors increase (Francuski et al., 2014; Illien-Junger et al., 2010; Le Maitre et al., 2004; Molinos et al., 2015; Pauli et al., 2011; Sztrolovics et al., 1997; Wuertz et al., 2009; Yin and Xia, 2014). The effect of osmolarity on the turnover of articular cartilage and IVD ECM is well documented (Amin et al., 2011; Ishihara et al., 1997; Johnson et al., 2014; Wuertz et al., 2007). In contrast to other tissues, osmolarity in healthy cartilage and IVDs raises to $430 \mathrm{mOsm} / \mathrm{kg}$, due to the presence of proteoglycans (Ishihara et al., 1997; van Dijk et al., 2011). In vitro cell and organ culture studies, performed in hypoosmotic (300-350 mOsm/kg), isosmotic (400-450 mOsm $/ \mathrm{kg}$ ) and hyperosmotic (500-600 $\mathrm{mOsm} / \mathrm{kg}$ ) conditions, show that both hypoosmotic and hyperosmotic environments alter the gene expression of structural ECM proteins and reduce water and biochemical content of cartilage and IVDs ECM (Chen et al., 2002; Li et al., 2016; Negoro et al., 2008; van Dijk et al., 2011; Wuertz et al., 2007). Interestingly, a hypoosmotic environment is more detrimental than hyperosmotic conditions: application of hyperosmotic saline solution $(600 \mathrm{mOsm} / \mathrm{kg})$ in articular cartilage explants reduces cell death after mechanical injury, when compared to normal (hypoosmotic) saline solution (285 mOsm/kg) (Amin et al., 2011). The osmotic environment surrounding chondrocytes and IVD cells is gradually altered during cartilage degeneration and aging, mainly due to a loss of proteoglycans (Adams and Roughley, 2006; Inoue and Espinoza Orias, 2011; Zhou et al., 2016). Therefore, balancing the age- and degeneration-related loss of accurate osmolarity is an important aim in the prevention and treatment of OA and DDD. However, it is yet not completely explained how chondrocytes and IVD cells sense their microenvironment and react to its changes. Uncovering cell surface receptors that are responsible for sensing local ECM structure/ composition and transformation of this information into cell responses is the first step in osmo-related drug development. Depending on their functionality, these receptors could then be inhibited or activated to balance the loss of osmolarity.

Both mechanically- and osmotically-induced volume change causes cell membrane stretch or ruffling, influencing cellular $\mathrm{Ca}^{2+}$ homeostasis by exposing or opening and closing $\mathrm{Ca}^{2+}$ channels (Degala et al., 2012; Liu and Montell, 2015). Swollen IVD cells and chondrocytes with a stretched plasma membrane are significantly more sensitive to $\mathrm{Ca}^{2+}$ influx than cells in isosmotic conditions (Pritchard and Guilak, 2004; Zhou et al., 2016). In chondrocytes, hypoosmotic shock causes rapid opening of stretchactivated cation (SAC) channels and TRPV channels, by activating the phospholipase C (PLC)-inositol 1,4,5-triphosphate (IP3) pathway (Sanchez et al., 2003). Responses of chondrocytes and IVD cells to varying extracellular osmolarity and the resulting $\mathrm{Ca}^{2+}$ level changes are mediated by calcineurin-independent transcription factor NFAT5 (TonEBP), which controls cellular homeostasis through expression of aquaporin 2, collagens, aggrecan, HSP70 and other targets including pro-inflammatory cytokines (Cheung and Ko, 2013; Gajghate et al., 2009; Johnson et al., 2014; Tsai et al., 2006). Furthermore, phospholipase C- $\gamma 1$ (PLC$\gamma 1)$-mediated activation of NFAT5 can contribute to NFAT5 transcriptional activity in HEK293 cells, under elevated $\mathrm{NaCl}$ conditions, suggesting a link between TRP channels and NFAT5 (Irarrazabal et al., 2010). However, relevant signalling pathways remain yet to be identified. Current results and hypotheses on how mechanical loading and osmolarity can regulate or be regulated by TRP channels are described below and in Fig. 2.

\section{TRPV}

TRPV2 is expressed in chondrocytes (Asmar et al., 2016) and IVD cells (Zvick, 2017), but little is known about its functional relevance in joint diseases. In retinal arterioles and cardiomyocytes, this channel is activated by stretching (Aguettaz et al., 2017; McGahon et al., 2016), supporting its emerging 
mechanosensor properties. Overexpression or overactivation of TRPV2, by non-physiological stretching in chondrocytes or IVD cells surrounded by degenerated ECM, could cause calcium overload that promotes cell deterioration and death (Berridge et al., 2000; Iatridis et al., 2006). Investigating the role of TRPV2 in mechanically-challenged tissues and organs, such as joints, is clearly warranted (Katanosaka et al., 2014).

TRPV4 is a major osmolarity-regulated ion channel in chondrocyte membranes, whose deletion accelerates the progression of OA in animal models (Clark et al., 2010; Kohler and Hoyer, 2007). In porcine articular chondrocytes, TRPV4-mediated $\mathrm{Ca}^{2+}$ signalling regulates osmolarity-induced volume change and subsequent release of prostaglandin E2 (PGE2), a mediator of hyperalgesia (Phan et al., 2009). The same cells treated with IL-1 $\beta$ show an impaired regulatory volume decrease in hypotonic conditions, being unable to reduce their size to counteract hypotonic swelling. Interestingly, this IL-1 $\beta$-induced effect is eliminated upon TRPV4 activation, indicating that TRPV4 may be involved in modulating inflammation in response to osmotic stress (Phan et al., 2009). In NP cells, reduced osmolarity activates the expression of TRPV4 and at the same time induces TRPV4-mediated $\mathrm{Ca}^{2+}$ signalling and gene expression of pro-inflammatory cytokines. Albeit based on the analysis of only one sample, it is proposed that TRPV4 expression is elevated in regions of aggrecan depletion in degenerated human IVD, indicating that TRPV4 can possibly play a role in swelling-related IVD inflammation and ECM breakdown (Walter et al., 2016). The authors suggest that reduced tissue osmolarity, following proteoglycan degradation, can increase TRPV4 signalling, enhance proinflammatory cytokine production and contribute to progressive matrix breakdown (Walter et al., 2016). The mechanism of osmolarity-dependent TRPV4 gene expression in chondrocytes includes phosphorylation of ERK1/2 (Hdud et al., 2014) and possibly also osmolarity-associated NFAT5 expression, but the role of NFAT5 in TRPV4-mediated effects has not yet been investigated.

Furthermore, TRPV4 plays a central role in chondrocyte responses to dynamic loading: inhibition of TRPV4 during dynamic loading of porcine agarose-embedded articular chondrocytes prevents expression of anabolic and anti-catabolic genes and reduces the loading-induced production of ECM (O'Conor et al., 2014). Interestingly, chemical activation of TRPV4 in the absence of mechanical loading has similar effects ( $\mathrm{O}^{\prime}$ Conor et al., 2014). As is apparent from aforementioned studies, activation of TRPV4 in chondrocytes can have both negative and positive effects. Current findings indicate that cellular consequences of TRPV4 activation depend on the surrounding ECM condition and that tight regulation of TRPV4-mediated $\mathrm{Ca}^{2+}$ signalling is important for the correct transduction of osmotic and mechanical signals in chondrocytes $\left(\mathrm{O}^{\prime}\right.$ Conor et al.,
2014). Therefore, it can be suggested that balanced therapeutic desensitisation or partial inhibition of dysregulated TRPV4-mediated osmotransduction and mechanotransduction, rather than total TRPV4 knockout/inhibition, can restore function of the ECM in treatments targeting cartilage or IVDs, including tissue-engineering approaches.

TRPV5/6 are highly $\mathrm{Ca}^{2+}$ selective and tightly regulated by intracellular $\mathrm{Ca}^{2+}$ concentration (van Abel et al., 2005). TRPV6 knockout mice suffer from severe osteoarthritis and loss of proteoglycans in articular cartilage (Song et al., 2017). Interestingly, reduced expression of TRPV6 was recently found in human OA cartilage and in rat OA model (Song et al., 2017), suggesting that TRPV6 deficiency affects chondrocyte function and homeostasis. Although it is known that TRPV-deficient mice suffer from osteopenia (Chen et al., 2014), very few data on the effects of TRPV6 dysregulation in the spinal connective tissue are available. TRPV6 expression is detected in IVD cells, but its exact role in IVD mechanosensing remains unclear (Zvick, 2017). As TRPV6 is clearly involved in regulating $\mathrm{Ca}^{2+}$ homeostasis of bone, its dysregulation may hypothetically aggravate Modic changes (Modic et al., 1988) of vertebral trabeculae or calcification of the endplates, both of which influence IVDs homeostasis and load distribution.

\section{TRPC}

It is suggested that members of TRPC family, particularly TRPC1 and TRPC6 are mechanicallygated and activated by tension across the lipid bilayer (Garrison et al., 2012; Maroto et al., 2005; Spassova et al., 2006). Mechanical stress at the plasma membrane is also shown to activate TRPC5 (Shen et al., 2015).

TRPC1, TRPC 3 and TRPC6 are expressed in chondrocytes (Gavenis et al., 2009) and IVD cells (Zvick, 2017), but their relevance for mechanosensing in OA and DDD remains largely unknown. It is suggested that balanced TRPC6 expression in chondrocytes is associated with phenotypic stability (Web Ref. 1), while TRPC6 overexpression in IVD cells correlates with cell differentiation and senescence (preliminary data). In murine chondrocytes, TRPC6 activation and subsequent calcium flux increases Akt phosphorylation and the expression of key molecular markers, suggesting TRPC6 as a possible therapeutic target in the prevention of articular cartilage breakdown during OA (Web Ref. 2). As multiple TRPC channels are mechanosensitive and a little is known about their relevance in OA and DDD, their therapeutic relevance should clearly be further investigated.

\section{TRP channels as therapeutic targets in joints}

TRP channels are involved in various aspects of cellular homeostasis, being attractive therapeutic targets if dysregulated. Impairment in TRP channels can be caused by inherited or acquired abnormalities in gene expression, post-transcriptional and posttranslational modifications or dysfunction of factors 
regulating the activity of TRP channels, many of which are unknown. Most conclusive data are available on the pathomechanisms of hereditary TRP-linked diseases (Nilius and Owsianik, 2010). The current understanding of acquired TRP channel disorders is limited, as it is mainly based on in vitro studies or rodent models, which do not always well represent human diseases (Kaneko and Szallasi, 2014).

One of the major challenges in treating TRP-linked disorders is related to the development of subtypespecific drugs (Moran et al., 2011). In addition to regulating a specific TRP channel, currently available antagonists and agonists often affect several other TRP channels in an unspecific manner, causing side effects (Kaneko and Szallasi, 2014). The function of TRP channels is also tissue-specific, as certain TRP channels can occur at different densities on different cell types. Therefore, not every tissue is affected in the same way by channel dysregulation. As an example, blockage of TRPM4 may be beneficial for the treatment of multiple sclerosis and anaphylaxis, but it may also cause cardiac arrhythmias and hypertension (Nilius and Voets, 2013). This problem can be partially solved by directing TRP drugs into specific tissues by using drug delivery systems targeting a specific cell type. In the treatment of pain, an interesting approach can be to target specifically primary sensory nociceptors by introducing a charged, membrane non-permeable lidocaine derivative (QX314), together with the TRPV1 activator capsaicin, through the TRPV1 pore. Upon activation and pore opening by capsaicin, QX-314 is taken up, specifically targeting sodium channels and inducing anaesthesia. This system shows promising effects on hyperalgesia in rats (Binshtok et al., 2007). Despite the challenges, several TRP agonists and antagonists have advanced to clinical trials (Kaneko and Szallasi, 2014). Another attractive approach to control overexpression and activation of TRP channels can be patient-specific, targeted genome editing techniques, such as CRISPR/Cas9, with minimised side effects. Detailed description of different TRP-targeting strategies was beyond the scope of this review and can be found in other review articles referenced in this chapter.

For joint disorders, inhibition of pain and improvement in quality of life is the most important result. OA and IVD-related pain is often caused by: (1) ingrowth of sensory nerve fibres into originally aneural tissue, (2) increased production and accumulation of nociceptive molecules, such as cytokines or neuropeptides, in affected joints and (3) tissue damage resulting from reduced mechanical stability. TRPA1 and TRPV1 are functionally expressed on sensory neurons, mediating nociceptive and neuropathic pain responses through interaction with algesic molecules that have accumulated in affected joints. Therefore, inhibition of neuronal TRPA1 and TRPV1 in OA and DDD can possibly alleviate pain symptoms. Selective agonists and antagonists of TRPA1 and TRPV1 are available and being tested as analgesics in pre-clinical and clinical trials for neuropathic and OA pain (Brito et al., 2014; Chen and Hackos, 2015; Moran et al., 2011). Challenges that may be associated with systemic use of these compounds are impaired sensing mechanisms in non-target tissues (e.g. reduced avoidance of pain) or side effects related to possible non-specificity (burning, itching). Local delivery of these compounds into OA joints and degenerated IVDs can substantially reduce their adverse effects. As an example, patches containing high-concentration of the TRPV1 agonist capsaicin, providing rapid and long-lasting pain relief in various neuropathic pain conditions, are already approved by the food and drug administration (FDA) (Baranidharan et al., 2013). Despite current efforts, pain inhibition treatments do not always target underlying pathophysiological mechanisms, allowing degenerative joint diseases to progress. Therefore, antagonising TRPA1 and TRPV1 on sensory neurons may reduce OA and DDD-related pain, but will not counteract joint degeneration. Evidence suggest that TRPA1 and TRPV1 expressed on other cell types, such as chondrocytes, can modulate mechanisms of inflammation (Fernandes et al., 2012). Specific targeting of inflammatory responses mediated by these channels in nonneuronal cells could possibly slow-down disease progression and, in unison, reduce all main pain mechanisms.

Overexpression of other TRP channels, such as TRPV4 or TRPC6, on chondrocytes may possibly lead to detrimental calcium overload or amplification of harmful signals, such as those induced by low $\mathrm{pH}$ or ROS, whereas under expression may cause a lack of homeostatic signals from ECM. TRPV4 is involved in cell-ECM communication in chondrocytes and IVD cells, as it senses the local osmotic environment and regulates cellular responses to microenvironmental changes in normal and degenerated joints (McNulty et al., 2015). Therefore, TRPV4 is a promising research candidate and possible therapeutic target in the treatment of age-related loss of ECM function in cartilaginous tissues. Also, TPRC6 may represent a useful target when aiming to prevent degenerative matrix changes or dedifferentiation of chondrocytes and IVD cells, specifically in the context of regenerative cell therapy, when phenotypic stability and reduction of senescence is crucial. Evidence suggests that other interesting targets, including TRPC1, TRPC3, TRPC4, TRPC5, TRPV6, TRPM2, TRPM7 and TRPM8, are possibly implicated in inflammation and mechanosensing in OA and DDD. In the treatment of OA and DDD, significantly dysregulated TRP channels (e.g. TRPA1, TRPV1 and TRPV4) can be therapeutically targeted using agonists/antagonists or genome editing methods. However, the treatment may be more challenging in case of other TRP channels (e.g. members of TRPC family), where a balance among several TRP channels may be more important than complete inhibition or activation of one channel. In such cases, smart 
drug delivery systems providing sustained release of multiple drugs or environmentally-responsive systems (e.g. drug release upon reduced osmolarity) may help solving the problem.

\section{Conclusions}

TRP channels are involved in sensing and regulation of osmotic, mechanical and inflammatory stress and pain in various tissues. Dysregulation of TRP channels is implicated in multiple diseases, such as cardiovascular disease, muscle dystrophies and possibly joint pathologies. As OA and DDD strongly correlate with mechanical and osmotic stress and inflammation, TRP channels are likely affected. Multiple TRP channels are expressed in chondrocytes and IVD cells. Furthermore, dysregulation of several TRP channels is linked with arthropathies, e.g. TRPA1 and TRPV1 with joint pain and inflammation and TRPV4 with reduced mechanical stability. However, the exact role of TRP channels in OA and DDD remains largely unexplored. We proposed that TRP channels can possibly constitute a link between mechanosensing, osmosensing and inflammatory regulation in chondrocytes and IVD cells and that the patient's age, genetic background, degree of degeneration and exogenous stress can influence specific TRP-mediated effects in OA and DDD. The interplay between molecular mechanisms underlying degeneration of cartilaginous tissues and TRP channels, as well as, the role of dysregulated TRP channels in OA and DDD, warrant further investigation. Hence, the significance of TRP channels, as therapeutic targets for the treatment of OA and DDD, should be assessed.

\section{Acknowledgements}

Financial support was obtained from the Swiss National Science Foundation (SNF PP00P2_163678/1), as well as, from the Spine Society of Europe (Eurospine 2016_4).

\section{References}

Aarts M, Iihara K, Wei WL, Xiong ZG, Arundine M, Cerwinski W, MacDonald JF, Tymianski M (2003) A key role for TRPM7 channels in anoxic neuronal death. Cell 115: 863-877.

Adams MA, Roughley PJ (2006) What is intervertebral disc degeneration, and what causes it?. Spine 31: 2151-2161.

Aguettaz E, Bois P, Cognard C, Sebille S (2017) Stretch-activated TRPV2 channels: role in mediating cardiopathies. Prog Biophys Mol Biol 17. DOI: 10.1016/j.pbiomolbio.2017.05.007.
Aijima R, Wang B, Takao T, Mihara H, Kashio M, Ohsaki Y, Zhang JQ, Mizuno A, Suzuki M, Yamashita Y, Masuko S, Goto M, Tominaga M, Kido MA (2015) The thermosensitive TRPV3 channel contributes to rapid wound healing in oral epithelia. FASEB J 29: 182-192.

Alawi KM, Russell FA, Aubdool AA, Srivastava S, Riffo-Vasquez Y, Baldissera L, Jr., Thakore P, Saleque N, Fernandes ES, Walsh DA, Brain SD (2017) Transient receptor potential canonical 5 (TRPC5) protects against pain and vascular inflammation in arthritis and joint inflammation. Ann Rheum Dis 76: 252-260.

Amin AK, Huntley JS, Patton JT, Brenkel IJ, Simpson AHRW, Hall AC (2011) Hyperosmolarity protects chondrocytes from mechanical injury in human articular cartilage. J Bone Joint Surg Br 93b: 277-284.

Andrei SR, Sinharoy P, Bratz IN, Damron DS (2016) TRPA1 is functionally co-expressed with TRPV1 in cardiac muscle: co-localization at z-discs, costameres and intercalated discs. Channels 10: 395409.

Aoki Y, Nakajima A, Ohtori S, Takahashi H, Watanabe F, Sonobe M, Terajima F, Saito M, Takahashi K, Toyone T, Watanabe A, Nakajima T, Takazawa M, Nakagawa K (2014) Increase of nerve growth factor levels in the human herniated intervertebral disc: can annular rupture trigger discogenic back pain? Arthritis Res Ther 16: R159.

Arniges M, Fernandez-Fernandez JM, Albrecht N, Schaefer M, Valverde MA (2006) Human TRPV4 channel splice variants revealed a key role of ankyrin domains in multimerization and trafficking. J Biol Chem 281: 1580-1586.

Asmar A, Barrett-Jolley R, Werner A, Kelly R, Jr., Stacey M (2016) Membrane channel gene expression in human costal and articular chondrocytes. Organogenesis 12: 94-107.

Atoyan R, Shander D, Botchkareva NV (2009) Nonneuronal expression of transient receptor potential type A1 (TRPA1) in human skin. J Invest Dermatol 129: 2312-2315.

Balzer M, Lintschinger B, Groschner K (1999) Evidence for a role of Trp proteins in the oxidative stress-induced membrane conductances of porcine aortic endothelial cells. Cardiovasc Res 42: 543-549.

Bandell M, Story GM, Hwang SW, Viswanath V, Eid SR, Petrus MJ, Earley TJ, Patapoutian A (2004) Noxious cold ion channel TRPA1 is activated by pungent compounds and bradykinin. Neuron 41: 849-857.

Baranidharan G, Das S, Bhaskar A (2013) A review of the high-concentration capsaicin patch and experience in its use in the management of neuropathic pain. Ther Adv Neurol Diso 6: 287-297.

Barbet G, Demion M, Moura IC, Serafini N, Leger T, Vrtovsnik F, Monteiro RC, Guinamard R, Kinet JP, Launay P (2008) The calcium-activated nonselective cation channel TRPM4 is essential for 
the migration but not the maturation of dendritic cells. Nat Immunol 9: 1148-1156.

Bautista DM, Jordt SE, Nikai T, Tsuruda PR, Read AJ, Poblete J, Yamoah EN, Basbaum AI, Julius D (2006) TRPA1 mediates the inflammatory actions of environmental irritants and proalgesic agents. Cell 124: 1269-1282.

Bautista DM, Siemens J, Glazer JM, Tsuruda PR, Basbaum AI, Stucky CL, Jordt SE, Julius D (2007) The menthol receptor TRPM8 is the principal detector of environmental cold. Nature 448: 204-208.

Behrendt HJ, Germann T, Gillen C, Hatt H, Jostock R (2004) Characterization of the mouse cold-menthol receptor TRPM8 and vanilloid receptor type-1 VR1 using a fluorometric imaging plate reader (FLIPR) assay. Br J Pharmacol 141: 737-745.

Beny Y, Kimchi T (2016) Conditioned odor aversion induces social anxiety towards females in wild-type and TrpC2 knockout male mice. Genes Brain Behav 15: 722-732.

Berenbaum F (2013) Osteoarthritis as an inflammatory disease (osteoarthritis is not osteoarthrosis!). Osteoarthr Cartilage 21: 16-21.

Berridge MJ, Lipp P, Bootman MD (2000) The versatility and universality of calcium signalling. Nat Rev Mol Cell Bio 1: 11-21.

Bessac BF, Sivula M, Von Hehn CA, Escalera J, Cohn L, Jordt SE (2008) TRPA1 is a major oxidant sensor in murine airway sensory neurons. J Clin Invest 118: 1899-1910.

Bezzerides VJ, Ramsey IS, Kotecha S, Greka A, Clapham DE (2004) Rapid vesicular translocation and insertion of TRP channels. Nat Cell Biol 6: 709-720.

Bianco SD, Peng JB, Takanaga H, Suzuki Y, Crescenzi A, Kos CH, Zhuang L, Freeman MR, Gouveia CH, Wu J, Luo H, Mauro T, Brown EM, Hediger MA (2007) Marked disturbance of calcium homeostasis in mice with targeted disruption of the Trpv6 calcium channel gene. J Bone Miner Res 22: 274-285.

Binshtok AM, Bean BP, Woolf CJ (2007) Inhibition of nociceptors by TRPV1-mediated entry of impermeant sodium channel blockers. Nature 449: 607-U613.

Birder LA, Nakamura Y, Kiss S, Nealen ML, Barrick S, Kanai AJ, Wang E, Ruiz G, de Groat WC, Apodaca G, Watkins S, Caterina MJ (2002) Altered urinary bladder function in mice lacking the vanilloid receptor TRPV1. Nat Neurosci 5: 856-860.

Birnbaumer L (2009) The TRPC class of ion channels: a critical review of their roles in slow, sustained increases in intracellular Ca2+ concentrations. Annu Rev Pharmacol 49: 395-426.

Boesmans W, Owsianik G, Tack J, Voets T, Vanden Berghe P (2011) TRP channels in neurogastroenterology: opportunities for therapeutic intervention. Br J Pharmacol 162: 18-37.

Bootman MD (2012) Calcium signaling. Cold Spring Harb Perspect Biol 4: a011171.

Boulter C, Mulroy S, Webb S, Fleming S, Brindle K, Sandford R (2001) Cardiovascular, skeletal, and renal defects in mice with a targeted disruption of the Pkd1 gene. Proc Natl Acad Sci U S A 98: 12174-12179.

Brain SD (2011) TRPV1 and TRPA1 channels in inflammatory pain: elucidating mechanisms. Ann N Y Acad Sci 1245: 36-37.

Brini M, Cali T, Ottolini D, Carafoli E (2014) Neuronal calcium signaling: function and dysfunction. Cell Mol Life Sci 71: 2787-2814.

Brito R, Sheth S, Mukherjea D, Rybak LP, Ramkumar V (2014) TRPV1: a potential drug target for treating various diseases. Cells 3: 517-545.

Buch TRH, Schafer EAM, Demmel MT, Boekhoff I, Thiermann H, Gudermann T, Steinritz D, Schmidt A (2013) Functional expression of the transient receptor potential channel TRPA1, a sensor for toxic lung inhalants, in pulmonary epithelial cells. Chem Biol Interact 206: 462-471.

Bush EW, Hood DB, Papst PJ, Chapo JA, Minobe W, Bristow MR, Olson EN, McKinsey TA (2006) Canonical transient receptor potential channels promote cardiomyocyte hypertrophy through activation of calcineurin signaling. J Biol Chem 281: 33487-33496.

Calabria E, Ciciliot S, Moretti I, Garcia M, Picard A, Dyar KA, Pallafacchina G, Tothova J, Schiaffino S, Murgia M (2009) NFAT isoforms control activitydependent muscle fiber type specification. Proc Natl Acad Sci U S A 106: 13335-13340.

Caterina MJ, Leffler A, Malmberg AB, Martin WJ, Trafton J, Petersen-Zeitz KR, Koltzenburg M, Basbaum AI, Julius D (2000) Impaired nociception and pain sensation in mice lacking the capsaicin receptor. Science 288: 306-313.

Chandra M, Zhou H, Li Q, Muallem S, Hofmann SL, Soyombo AA (2011) A role for the Ca2+ channel TRPML1 in gastric acid secretion, based on analysis of knockout mice. Gastroenterology 140: 857-867.

Chen FJ, Ni B, Yang YPO, Ye TW, Chen AM (2014) Knockout of TRPV6 Causes osteopenia in mice by increasing osteoclastic differentiation and activity. Cell Physiol Biochem 33: 796-809.

Chen J, Baer AE, Paik PY, Yan W, Setton LA (2002) Matrix protein gene expression in intervertebral disc cells subjected to altered osmolarity. Biochem Biophys Res Commun 293: 932-938.

Chen J, Hackos DH (2015) TRPA1 as a drug targetpromise and challenges. Naunyn Schmiedebergs Arch Pharmacol 388: 451-463.

Chen Y, Willcockson HH, Valtschanoff JG (2009) Vanilloid receptor TRPV1-mediated phosphorylation of ERK in murine adjuvant arthritis. Osteoarthritis Cartilage 17: 244-251.

Cheung CY, Ko BC (2013) NFAT5 in cellular adaptation to hypertonic stress - regulations and functional significance. J Mol Signal 8: 5.

Chuang HH, Neuhausser WM, Julius D (2004) The super-cooling agent icilin reveals a mechanism of coincidence detection by a temperature-sensitive TRP channel. Neuron 43: 859-869.

Clapham DE (2007) Calcium signaling. Cell 131: 1047-1058. 
Clark AL, Votta BJ, Kumar S, Liedtke W, Guilak F (2010) Chondroprotective role of the osmotically sensitive ion channel transient receptor potential vanilloid 4 age- and sex-dependent progression of osteoarthritis in Trpv4-deficient mice. Arthritis Rheum 62: 2973-2983.

Colburn RW, Lubin ML, Stone DJ, Jr., Wang Y, Lawrence D, D'Andrea MR, Brandt MR, Liu Y, Flores CM, Qin N (2007) Attenuated cold sensitivity in TRPM8 null mice. Neuron 54: 379-386.

Cramer GD, Darby S (1997) Basic and clinical anatomy of the spine, spinal cord, and ANS. J Manipulative Physiol Ther 20: 294-294.

Cullen PJ (2003) Calcium signalling: the ups and downs of protein kinase C. Curr Biol 13: R699-R701.

Davis JB, Gray J, Gunthorpe MJ, Hatcher JP, Davey PT, Overend P, Harries MH, Latcham J, Clapham C, Atkinson K, Hughes SA, Rance K, Grau E, Harper AJ, Pugh PL, Rogers DC, Bingham S, Randall A, Sheardown SA (2000) Vanilloid receptor-1 is essential for inflammatory thermal hyperalgesia. Nature 405: 183-187.

Degala S, Williams R, Zipfel W, Bonassar LJ (2012) Calcium signaling in response to fluid flow by chondrocytes in $3 \mathrm{D}$ alginate culture. J Orthop Res 30: 793-799.

Demion M, Thireau J, Gueffier M, Finan A, Khoueiry Z, Cassan C, Serafini N, Aimond F, Granier M, Pasquie JL, Launay P, Richard S (2014) Trpm4 gene invalidation leads to cardiac hypertrophy and electrophysiological alterations. PLoS One 9: e115256.

Desai BN, Clapham DE (2005) TRP channels and mice deficient in TRP channels. Pflugers Arch 451: 11-18.

Dhaka A, Murray AN, Mathur J, Earley TJ, Petrus MJ, Patapoutian A (2007) TRPM8 is required for cold sensation in mice. Neuron 54: 371-378.

Dhaka A, Uzzell V, Dubin AE, Mathur J, Petrus M, Bandell M, Patapoutian A (2009) TRPV1 is activated by both acidic and basic $\mathrm{pH}$. J Neurosci 29: 153-158.

$\mathrm{Du}$ J, Ma X, Shen B, Huang Y, Birnbaumer L, Yao $X$ (2014) TRPV4, TRPC1, and TRPP2 assemble to form a flow-sensitive heteromeric channel. FASEB J 28: 4677-4685.

Eckel J, Lavin PJ, Finch EA, Mukerji N, Burch J, Gbadegesin R, Wu G, Bowling B, Byrd A, Hall G, Sparks M, Zhang ZS, Homstad A, Barisoni L, Birbaumer L, Rosenberg P, Winn MP (2011) TRPC6 enhances angiotensin II-induced albuminuria. J Am Soc Nephrol 22: 526-535.

Eid SR, Crown ED, Moore EL, Liang HA, Choong KC, Dima S, Henze DA, Kane SA, Urban MO (2008) HC-030031, a TRPA1 selective antagonist, attenuates inflammatory- and neuropathy-induced mechanical hypersensitivity. Mol Pain 4: 48.

Entin-Meer M, Cohen L, Hertzberg-Bigelman E, Levy R, Ben-Shoshan J, Keren G (2017) TRPV2 knockout mice demonstrate an improved cardiac performance following myocardial infarction due to attenuated activity of peri-infarct macrophages. PLoS One 12: e0177132.
Everett KV (2011) Transient receptor potential genes and human inherited disease. Adv Exp Med Biol 704: 1011-1032.

Fang X, Shi XH, Huang LB, Rong WF, Ma B (2014) [Upregulation of P2X3 receptors in dorsal root ganglion of TRPV1 knockout female mice]. Sheng Li Xue Bao 66: 431-437.

Feng C, Yang M, Lan M, Liu C, Zhang Y, Huang B, Liu H, Zhou Y (2017) ROS: crucial intermediators in the pathogenesis of intervertebral disc degeneration. Oxid Med Cell Longev 2017: 5601593.

Fernandes ES, Fernandes MA, Keeble JE (2012) The functions of TRPA1 and TRPV1: moving away from sensory nerves. Br J Pharmacol 166: 510-521.

Fernandes ES, Russell FA, Spina D, McDougall JJ, Graepel R, Gentry C, Staniland AA, Mountford DM, Keeble JE, Malcangio M, Bevan S, Brain SD (2011) A distinct role for transient receptor potential ankyrin 1, in addition to transient receptor potential vanilloid 1, in tumor necrosis factor alpha-induced inflammatory hyperalgesia and freund's complete adjuvant-induced monarthritis. Arthritis Rheum 63: 819-829.

Fonfria E, Marshall ICB, Benham CD, Boyfield I, Brown JD, Hill K, Hughes JP, Skaper SD, McNulty $S$ (2004) TRPM2 channel opening in response to oxidative stress is dependent on activation of poly(ADP-ribose) polymerase. Br J Pharmacol 143: 186-192.

Franceschi C, Bonafe M (2003) Centenarians as a model for healthy aging. Biochem Soc Trans 31: 457461.

Francuski JV, Radovanovic A, Andric N, Krstic V, Bogdanovic D, Hadzic V, Todorovic V, Macanovic ML, Petit SS, Beck-Cormier S, Guicheux J, Gauthier O, Filipovic MK (2014) Age-related changes in the articular cartilage of the stifle joint in non-working and working German shepherd dogs. J Comp Pathol 151: 363-374.

Freemont AJ, Peacock TE, Goupille P, Hoyland JA, OBrien J, Jayson MIV (1997) Nerve ingrowth into diseased intervertebral disc in chronic back pain. Lancet 350: 178-181.

Freichel M, Vennekens R, Olausson J, Hoffmann M, Muller C, Stolz S, Scheunemann J, Weissgerber P, Flockerzi V (2004) Functional role of TRPC proteins in vivo: lessons from TRPC-deficient mouse models. Biochem Biophys Res Commun 322: 1352-1358.

Gajghate S, Hiyama A, Shah M, Sakai D, Anderson DG, Shapiro IM, Risbud MV (2009) Osmolarity and intracellular calcium regulate aquaporin2 expression through TonEBP in nucleus pulposus cells of the intervertebral disc. J Bone Miner Res 24: 992-1001.

Galbusera F, van Rijsbergen M, Ito K, Huyghe JM, Brayda-Bruno M, Wilke HJ (2014) Ageing and degenerative changes of the intervertebral disc and their impact on spinal flexibility. Eur Spine J 23 Suppl 3: S324-332.

Gallego-Sandin S, Rodriguez-Garcia A, Alonso MT, Garcia-Sancho J (2009) The endoplasmic reticulum of dorsal root ganglion neurons contains 
functional TRPV1 channels. J Biol Chem 284: 3259132601.

Garrison SR, Dietrich A, Stucky CL (2012) TRPC1 contributes to light-touch sensation and mechanical responses in low-threshold cutaneous sensory neurons. J Neurophysiol 107: 913-922.

Gavenis K, Schumacher C, Schneider U, Eisfeld J, Mollenhauer J, Schmidt-Rohlfing B (2009) Expression of ion channels of the TRP family in articular chondrocytes from osteoarthritic patients: changes between native and in vitro propagated chondrocytes. Mol Cell Biochem 321: 135-143.

Gawri R, Moir J, Ouellet J, Beckman L, Steffen T, Roughley P, Haglund L (2014) Physiological loading can restore the proteoglycan content in a model of early IVD degeneration. PLoS One 9: e101233.

Gees M, Colsoul B, Nilius B (2010) The role of transient receptor potential cation channels in $\mathrm{Ca} 2+$ signaling. Cold Spring Harb Perspect Biol 2: a003962.

Goldring MB, Otero M (2011) Inflammation in osteoarthritis. Curr Opin Rheumatol 23: 471-478.

Grassel S (2014) The role of peripheral nerve fibers and their neurotransmitters in cartilage and bone physiology and pathophysiology. Arthritis Res Ther 16: 485 .

Grimm C, Hassan S, Wahl-Schott C, Biel M (2012) Role of TRPML and two-pore channels in endolysosomal cation homeostasis. J Pharmacol Exp Ther 342: 236-244.

Guler AD, Lee HS, Iida T, Shimizu I, Tominaga M, Caterina M (2002) Heat-evoked activation of the ion channel, TRPV4. J Neurosci 22: 6408-6414.

Halliday DA, Zettler C, Rush RA, Scicchitano R, McNeil JD (1998) Elevated nerve growth factor levels in the synovial fluid of patients with inflammatory joint disease. Neurochem Res 23: 919-922.

Hamano K, Kawanishi T, Mizuno A, Suzuki M, Takagi Y (2016) Involvement of transient receptor potential vanilloid (TRPV) 4 in mouse sperm thermotaxis. J Reprod Dev 62: 415-422.

Han E, Chen SS, Klisch SM, Sah RL (2011) Contribution of proteoglycan osmotic swelling pressure to the compressive properties of articular cartilage. Biophys J 101: 916-924.

Hartmann J, Dragicevic E, Adelsberger H, Henning HA, Sumser M, Abramowitz J, Blum R, Dietrich A, Freichel M, Flockerzi V, Birnbaumer L, Konnerth A (2008) TRPC3 channels are required for synaptic transmission and motor coordination. Neuron 59: 392-398.

Hatano N, Itoh Y, Suzuki H, Muraki Y, Hayashi H, Onozaki K, Wood IC, Beech DJ, Muraki K (2012a) Hypoxia-inducible Factor-1 alpha (HIF1 alpha) Switches on transient receptor potential ankyrin repeat 1 (TRPA1) gene expression via a hypoxia response element-like motif to modulate cytokine release. J Biol Chem 287: 31962-31972.

Hatano N, Itoh Y, Suzuki H, Muraki Y, Hayashi H, Onozaki K, Wood IC, Beech DJ, Muraki K (2012b) Hypoxia-inducible factor-1alpha (HIF1alpha) switches on transient receptor potential ankyrin repeat 1 (TRPA1) gene expression via a hypoxia response element-like motif to modulate cytokine release. J Biol Chem 287: 31962-31972.

Hdud IM, Mobasheri A, Loughna PT (2014) Effect of osmotic stress on the expression of TRPV4 and BKCa channels and possible interaction with ERK1/2 and p38 in cultured equine chondrocytes. Am J Physiol Cell Physiol 306: C1050-C1057.

Henschke N, Maher CG, Refshauge KM, Herbert RD, Cumming RG, Bleasel J, York J, Das A, McAuley JH (2008) Prognosis in patients with recent onset low back pain in Australian primary care: inception cohort study. BMJ 337: a171.

Hoenderop JGJ, van Leeuwen JPTM, van der Eerden BCJ, Kersten FFJ, van der Kemp AWCM, Merillat AM, Waarsing JH, Rossier BC, Vallon V, Hummler E, Bindels RJM (2003) Renal Ca2+ wasting, hyperabsorption, and reduced bone thickness in mice lacking TRPV5. J Clin Invest 112: 1906-1914.

Horváth Á, Tékus V, Boros M, Pozsgai G, Botz B, Borbely E, Szolcsanyi J, Pinter E, Helyes Z (2016) Transient receptor potential ankyrin 1 (TRPA1) receptor is involved in chronic arthritis: in vivo study using TRPA1-deficient mice. Arthritis Res Ther 18: 6.

Hoy D, Brooks P, Blyth F, Buchbinder R (2010a) The Epidemiology of low back pain. Best Pract Res Clin Rheumatol 24: 769-781.

Hoy D, March L, Brooks P, Woolf A, Blyth F, Vos T, Buchbinder R (2010b) Measuring the global burden of low back pain. Best Pract Res Clin Rheumatol 24: 155-165.

Iatridis JC, MacLean JJ, Roughley PJ, Alini M (2006) Effects of mechanical loading on intervertebral disc metabolism in vivo. J Bone Joint Surg Am 88 Suppl 2: 41-46.

Iida T, Shimizu I, Nealen ML, Campbell A, Caterina M (2005) Attenuated fever response in mice lacking TRPV1. Neurosci Lett 378: 28-33.

Illien-Junger S, Gantenbein-Ritter B, Grad S, Lezuo P, Ferguson SJ, Alini M, Ito K (2010) The combined effects of limited nutrition and high-frequency loading on intervertebral discs with endplates. Spine (Phila Pa 1976) 35: 1744-1752.

Inoue N, Espinoza Orias AA (2011) Biomechanics of intervertebral disk degeneration. Orthop Clin North Am 42: 487-499.

Irarrazabal CE, Gallazzini M, Schnetz MP, Kunin M, Simons BL, Williams CK, Burg MB, Ferraris JD (2010) Phospholipase C-gamma 1 is involved in signaling the activation by high $\mathrm{NaCl}$ of the osmoprotective transcription factor TonEBP/OREBP. Proc Natl Acad Sci U S A 107: 906-911.

Ishihara H, Warensjo K, Roberts S, Urban JP (1997) Proteoglycan synthesis in the intervertebral disk nucleus: the role of extracellular osmolality. Am J Physiol 272: C1499-1506.

Ishikura T, Suzuki H, Shoguchi K, Koreeda Y, Aritomi T, Matsuura T, Yoshimura M, Ohkubo J, Maruyama T, Kawasaki M, Ohnishi H, Sakai A, Mizuno A, Suzuki M, Ueta Y (2015) Possible involvement of TRPV1 and TRPV4 in nociceptive 
stimulation-induced nocifensive behavior and neuroendocrine response in mice. Brain Res Bull 118: 7-16.

Hoyland JA, Le Maitre C, Freemont AJ (2009) Investigation of the role of IL-1 and TNF in matrix degradation in the intervertebral disc. Rheumatology (Oxford) 47 : 809-914

Ito K, Creemers L (2013) Mechanisms of intervertebral disk degeneration/injury and pain: a review. Global Spine J 3: 145-152.

Janssen DA, Hoenderop JG, Heesakkers JP, Schalken JA (2016) TRPV4 mediates afferent pathways in the urinary bladder. A spinal c-fos study showing TRPV1 related adaptations in the TRPV4 knockout mouse. Pflugers Arch 468: 1741-1749.

Johnson ZI, Schoepflin ZR, Choi H, Shapiro IM, Risbud MV (2015) Disc in flames: roles of TNF-alpha and IL-1 beta in intervertebral disc degeneration. Eur Cell Mater 30: 104-117.

Johnson ZI, Shapiro IM, Risbud MV (2014) Extracellular osmolarity regulates matrix homeostasis in the intervertebral disc and articular cartilage: evolving role of TonEBP. Matrix Biol 40: 10-16.

Kaneko Y, Szallasi A (2014) Transient receptor potential ( TRP) channels: a clinical perspective. Br J Pharmacol 171: 2474-2507.

Karashima Y, Talavera K, Everaerts W, Janssens A, Kwan KY, Vennekens R, Nilius B, Voets T (2009) TRPA1 acts as a cold sensor in vitro and in vivo. Proc Natl Acad Sci U S A 106: 1273-1278.

Katanosaka Y, Iwasaki K, Ujihara Y, Takatsu S, Nishitsuji K, Kanagawa M, Sudo A, Toda T, Katanosaka K, Mohri S, Naruse K (2014) TRPV2 is critical for the maintenance of cardiac structure and function in mice. Nat Commun 5: 3932.

Keeble J, Russell F, Curtis B, Starr A, Pinter E, Brain SD (2005) Involvement of transient receptor potential vanilloid 1 in the vascular and hyperalgesic components of joint inflammation. Arthritis Rheum 52: 3248-3256.

Kelly S, Chapman RJ, Woodhams S, Sagar DR, Turner J, Burston JJ, Bullock C, Paton K, Huang J, Wong A, McWilliams DF, Okine BN, Barrett DA, Hathway GJ, Walsh DA, Chapman V (2015) Increased function of pronociceptive TRPV1 at the level of the joint in a rat model of osteoarthritis pain. Ann Rheum Dis 74: 252-259.

Kepler CK, Markova DZ, Hilibrand AS, Vaccaro AR, Risbud MV, Albert TJ, Anderson DG (2013) Substance P stimulates production of inflammatory cytokines in human disc cells. Spine (Phila Pa 1976) 38: E1291-1299.

Kim I, Ding T, Fu Y, Li C, Cui L, Li A, Lian P, Liang D, Wang DW, Guo C, Ma J, Zhao P, Coffey RJ, Zhan Q, Wu G (2009) Conditional mutation of Pkd2 causes cystogenesis and upregulates beta-catenin. J Am Soc Nephrol 20: 2556-2569.

Knowles H, Heizer JW, Li Y, Chapman K, Ogden CA, Andreasen K, Shapland E, Kucera G, Mogan J, Humann J, Lenz LL, Morrison AD, Perraud AL (2011) Transient receptor potential melastatin 2 (TRPM2) ion channel is required for innate immunity against Listeria monocytogenes. Proc Natl Acad Sci U S A 108: 11578-11583.

Kochukov MY, Balasubramanian A, Noel RC, Marrelli SP (2013) Role of TRPC1 and TRPC3 channels in contraction and relaxation of mouse thoracic aorta. J Vasc Res 50: 11-20.

Kohler R, Hoyer J (2007) Role of TRPV4 in the mechanotransduction of shear stress in endothelial cells. Liedtke WB, Heller S, editors. TRP ion channel function in sensory transduction and cellular signaling cascades. Boca Raton (FL): CRC Press/ Taylor \& Francis 27.

Kun J, Szitter I, Kemeny A, Perkecz A, Kereskai L, Pohoczky K, Vincze A, Godi S, Szabo I, Szolcsanyi J, Pinter E, Helyes Z (2014) Upregulation of the transient receptor potential ankyrin 1 ion channel in the inflamed human and mouse colon and its protective roles. PLoS One 9: e108164.

Kwan KY, Allchorne AJ, Vollrath MA, Christensen AP, Zhang DS, Woolf CJ, Corey DP (2006) TRPA1 contributes to cold, mechanical, and chemical Nociception but is not essential for hair-cell transduction. Neuron 50: 277-289.

Larsson MH, Hakansson P, Jansen FP, Magnell K, Brodin P (2015) Ablation of TRPM5 in mice results in reduced body weight gain and improved glucose tolerance and protects from excessive consumption of sweet palatable food when fed high caloric diets. PLoS One 10: e0138373.

Lau OC, Shen B, Wong CO, Tjong YW, Lo CY, Wang HC, Huang Y, Yung WH, Chen YC, Fung ML, Rudd JA, Yao X (2016) TRPC5 channels participate in pressure-sensing in aortic baroreceptors. Nat Commun 7: 11947.

Lawrence RC, Felson DT, Helmick CG, Arnold LM, Choi H, Deyo RA, Gabriel S, Hirsch R, Hochberg MC, Hunder GG, Jordan JM, Katz JN, Kremers HM, Wolfe F, Workgrp NAD (2008) Estimates of the prevalence of arthritis and other rheumatic conditions in the United States. Arthritis Rheum 58: 26-35.

Le Maitre CL, Freemont AJ, Hoyland JA (2004) Localization of degradative enzymes and their inhibitors in the degenerate human intervertebral disc. J Pathol 204: 47-54.

Le Maitre CL, Freemont AJ, Hoyland JA (2007) Accelerated cellular senescence in degenerate intervertebral discs: a possible role in the pathogenesis of intervertebral disc degeneration. Arthritis Res Ther 9: R45.

Leypold BG, Yu CR, Leinders-Zufall T, Kim MM, Zufall F, Axel R (2002) Altered sexual and social behaviors in trp2 mutant mice. Proc Natl Acad Sci U S A 99: 6376-6381.

Li P, Gan YB, Xu Y, Li ST, Song L, Li SK, Li HJ, Zhou Q (2016) Osmolarity affects matrix synthesis in the nucleus pulposus associated with the involvement of MAPK pathways: a study of ex vivo disc organ culture system. J Orthop Res 34: 1092-1100.

Li S, Xu W, Xing Z, Qian J, Chen L, Gu R, Guo W, Lai X, Zhao W, Li S, Wang Y, Wang QJ, Deng F 
(2017) A conditional knockout mouse model reveals a critical role of PKD1 in osteoblast differentiation and bone development. Sci Rep 7: 40505.

Liedtke W, Friedman JM (2003) Abnormal osmotic regulation in trpv4(-/-) mice. Proc Natl Acad Sci U S A 100: 13698-13703.

Lindemann O, Strodthoff C, Horstmann M, Nielsen N, Jung F, Schimmelpfennig S, Heitzmann M, Schwab A (2015) TRPC1 regulates fMLP-stimulated migration and chemotaxis of neutrophil granulocytes. Biochim Biophys Acta 1853: 2122-2130.

Liu B, Goode AP, Carter TE, Utturkar GM, Huebner JL, Taylor DC, Moorman Iii CT, Garrett WE, Kraus VB, Guilak F, DeFrate LE, McNulty AL (2016) Matrix metalloproteinase activity and prostaglandin E2 are elevated in the synovial fluid of meniscus tear patients. Connect Tissue Res 58: 305-316.

Liu C, Montell C (2015) Forcing open TRP channels: mechanical gating as a unifying activation mechanism. Biochem Biophys Res Commun 460: 2225.

Liu X, Cotrim A, Teos L, Zheng C, Swaim W, Mitchell J, Mori Y, Ambudkar I (2013) Loss of TRPM2 function protects against irradiation-induced salivary gland dysfunction. Nat Commun 4: 1515.

Malczyk M, Veith C, Fuchs B, Hofmann K, Storch U, Schermuly RT, Witzenrath M, Ahlbrecht K, FecherTrost C, Flockerzi V, Ghofrani HA, Grimminger F, Seeger W, Gudermann T, Dietrich A, Weissmann N (2013) Classical transient receptor potential channel 1 in hypoxia-induced pulmonary hypertension. Am J Respir Crit Care Med 188: 1451-1459.

Maroto R, Raso A, Wood TG, Kurosky A, Martinac B, Hamill OP (2005) TRPC1 forms the stretchactivated cation channel in vertebrate cells. Nat Cell Biol 7: 179-185.

Maroudas A (1976) Balance between swelling pressure and collagen tension in normal and degenerate cartilage. Nature 260: 808-809.

Mathar I, Kecskes M, Van der Mieren G, Jacobs G, Camacho Londono JE, Uhl S, Flockerzi V, Voets T, Freichel M, Nilius B, Herijgers P, Vennekens R (2014) Increased beta-adrenergic inotropy in ventricular myocardium from Trpm4-/- mice. Circ Res 114: 283294.

McGahon MK, Fernandez JA, Dash DP, McKee J, Simpson DA, Zholos AV, McGeown JG, Curtis TM (2016) TRPV2 channels contribute to stretch-activated cation currents and myogenic constriction in retinal arterioles. Invest Ophthalmol Vis Sci 57: 5637-5647.

McNulty AL, Leddy HA, Liedtke W, Guilak F (2015) TRPV4 as a therapeutic target for joint diseases. Naunyn Schmiedebergs Arch Pharmacol 388: $437-$ 450.

McNulty AL, Weinberg JB, Guilak F (2009) Inhibition of matrix metalloproteinases enhances in vitro repair of the meniscus. Clin Orthop Relat Res 467: 1557-1567.

Micsenyi MC, Dobrenis K, Stephney G, Pickel J, Vanier MT, Slaugenhaupt SA, Walkley SU (2009) Neuropathology of the Mcoln1(-/-) knockout mouse model of mucolipidosis type IV. J Neuropathol Exp Neurol 68: 125-135.

Mizuno A, Matsumoto N, Imai M, Suzuki M (2003) Impaired osmotic sensation in mice lacking TRPV4. Am J Physiol Cell Physiol 285: C96-101.

Mobasheri A, Matta C, Zakany R, Musumeci G (2015) Chondrosenescence: definition, hallmarks and potential role in the pathogenesis of osteoarthritis. Maturitas 80: 237-244.

Modic MT, Masaryk TJ, Ross JS, Carter JR (1998) Imaging of degenerative disk disease. Radiology 168: 177-186.

Molinos M, Almeida CR, Caldeira J, Cunha C, Goncalves RM, Barbosa MA (2015) Inflammation in intervertebral disc degeneration and regeneration. J R Soc Interface 12: 20150429.

Montell C, Birnbaumer L, Flockerzi V, Bindels RJ, Brudorf EA, Caterina MJ, Clapham DE, Harteneck C, Heller S, Julius D, Kojima I, Mori Y, Penner R, Prawitt D, Scharenberg AM, Schultz G, Shimizu N, Zhu MX (2002) A unified nomenclature for the superfamily of TRP cation channels. Mol Cell 9: 229-231.

Moqrich A, Hwang SW, Earley TJ, Petrus MJ, Murray AN, Spencer KSR, Andahazy M, Story GM, Patapoutian A (2005) Impaired thermosensation in mice lacking TRPV3, a heat and camphor sensor in the skin. Science 307: 1468-1472.

Moran MM, McAlexander MA, Biro T, Szallasi A (2011) Transient receptor potential channels as therapeutic targets. Nat Rev Drug Discov 10: 601-620.

Morenilla-Palao C, Planells-Cases R, Garcia-Sanz N, Ferrer-Montiel A (2004) Regulated exocytosis contributes to protein kinase $\mathrm{C}$ potentiation of vanilloid receptor activity. J Biol Chem 279: 2566525672.

Morgans CW, Zhang J, Jeffrey BG, Nelson SM, Burke NS, Duvoisin RM, Brown RL (2009) TRPM1 is required for the depolarizing light response in retinal ON-bipolar cells. Proc Natl Acad Sci U S A 106: 19174-19178.

Negoro K, Kobayashi S, Takeno K, Uchida K, Baba $\mathrm{H}$ (2008) Effect of osmolarity on glycosaminoglycan production and cell metabolism of articular chondrocyte under three-dimensional culture system. Clin Exp Rheumatol 26: 534-541.

Neogi T (2013) The epidemiology and impact of pain in osteoarthritis. Osteoarthritis Cartilage 21: 1145-1153.

Nie X, Arend LJ (2013) Pkd1 is required for male reproductive tract development. Mech Dev 130: 567576.

Nie X, Arend LJ (2014) Novel roles of Pkd2 in male reproductive system development. Differentiation 87: 161-171.

Nilius B, Appendino G, Owsianik G (2012) The transient receptor potential channel TRPA1: from gene to pathophysiology. Pflugers Arch 464: 425-458.

Nilius B, Owsianik G (2010) Transient receptor potential channelopathies. P Pflugers Arch 460: 437450. 
Nilius B, Owsianik G (2011) The transient receptor potential family of ion channels. Genome Biol 12: 218.

Nilius B, Voets T (2013) The puzzle of TRPV4 channelopathies. EMBO Reports 14: 152-163.

Nishijima Y, Zheng X, Lund H, Suzuki M, Mattson DL, Zhang DX (2014) Characterization of blood pressure and endothelial function in TRPV4-deficient mice with 1-NAME- and angiotensin II-induced hypertension. Physiol Rep 2: e00199.

Numata T, Kiyonaka S, Kato K, Takahashi N, Mori Y (2011) Activation of TRP channels in mammalian systems. In: Zhu MX, editor. TRP Channels. Boca Raton (FL): CRC Press/Taylor \& Francis 3.

Nummenmaa E, Hamalainen M, Moilanen LJ, Paukkeri EL, Nieminen RM, Moilanen T, Vuolteenaho K, Moilanen E (2016) Transient receptor potential ankyrin 1 (TRPA1) is functionally expressed in primary human osteoarthritic chondrocytes. Arthritis Res Ther 18: 185.

O'Conor CJ, Griffin TM, Liedtke W, Guilak F (2013) Increased susceptibility of Trpv4-deficient mice to obesity and obesity-induced osteoarthritis with very high-fat diet. Ann Rheum Dis 72: 300-304.

O'Conor CJ, Leddy HA, Benefield HC, Liedtke WB, Guilak F (2014) TRPV4-mediated mechanotransduction regulates the metabolic response of chondrocytes to dynamic loading. Proc Natl Acad Sci U S A 111: 1316-1321.

O'Conor CJ, Ramalingam S, Zelenski NA, Benefield HC, Rigo I, Little D, Wu CL, Chen D, Liedtke W, McNulty AL, Guilak F (2016) Cartilagespecific knockout of the mechanosensory ion channel TRPV4 decreases age-related osteoarthritis. Sci Rep 6: 29053.

Oda H, Matsuzaki H, Tokuhashi Y, Wakabayashi K, Uematsu Y, Iwahashi M (2004) Degeneration of intervertebral discs due to smoking: experimental assessment in a rat-smoking model. J Orthop Sci 9: 135-141.

Okada Y, Shirai K, Reinach PS, Kitano-Izutani A, Miyajima M, Flanders KC, Jester JV, Tominaga M, Saika S (2014) TRPA1 is required for TGF-beta signaling and its loss blocks inflammatory fibrosis in mouse corneal stroma. Lab Invest 94: 1030-1041.

Pai S, Sundaram LJ (2004) Low back pain: an economic assessment in the United States. Orthop Clin North Am 35: 1-5.

Park U, Vastani N, Guan Y, Raja SN, Koltzenburg M, Caterina MJ (2011) TRP vanilloid 2 knock-out mice are susceptible to perinatal lethality but display normal thermal and mechanical nociception. J Neurosci 31: 11425-11436.

Patapoutian A, Tate S, Woolf CJ (2009) Transient receptor potential channels: targeting pain at the source. Nat Rev Drug Discov 8: 55-68.

Pauli C, Grogan SP, Patil S, Otsuki S, Hasegawa A, Koziol J, Lotz MK, D'Lima DD (2011) Macroscopic and histopathologic analysis of human knee menisci in aging and osteoarthritis. Osteoarthritis Cartilage 19: 1132-1141.
Peat G, McCarney R, Croft P (2001) Knee pain and osteoarthritis in older adults: a review of community burden and current use of primary health care. Ann Rheum Dis 60: 91-97.

Pecchi E, Priam S, Gosset M, Pigenet A, Sudre L, Laiguillon MC, Berenbaum F, Houard X (2014) Induction of nerve growth factor expression and release by mechanical and inflammatory stimuli in chondrocytes: possible involvement in osteoarthritis pain. Arthritis Res Ther 16: R16.

Phan MN, Leddy HA, Votta BJ, Kumar S, Levy DS, Lipshutz DB, Lee SH, Liedtke W, Guilak F (2009) Functional characterization of TRPV4 as an osmotically sensitive ion channel in porcine articular chondrocytes. Arthritis Rheum 60: 3028-3037.

Phelan KD, Shwe UT, Abramowitz J, Birnbaumer L, Zheng F (2014) Critical role of canonical transient receptor potential channel 7 in initiation of seizures. Proc Natl Acad Sci U S A 111: 11533-11538.

Phelan KD, Shwe UT, Abramowitz J, Wu H, Rhee SW, Howell MD, Gottschall PE, Freichel M, Flockerzi V, Birnbaumer L, Zheng F (2013) Canonical transient receptor channel 5 (TRPC5) and TRPC1/4 contribute to seizure and excitotoxicity by distinct cellular mechanisms. Mol Pharmacol 83: 429-438.

Phelan KD, Shwe UT, Cozart MA, Wu H, Mock MM, Abramowitz J, Birnbaumer L, Zheng F (2017) TRPC3 channels play a critical role in the theta component of pilocarpine-induced status epilepticus in mice. Epilepsia 58: 247-254.

Pritchard S, Guilak F (2004) The role of F-actin in hypo-osmotically induced cell volume change and calcium signaling in anulus fibrosus cells. Ann Biomed Eng 32: 103-111.

Qian F, Huang P, Ma L, Kuznetsov A, Tamarina N, Philipson LH (2002) TRP genes: candidates for nonselective cation channels and store-operated channels in insulin-secreting cells. Diabetes 51 Suppl 1: S183-189.

Ramsey IS, Delling M, Clapham DE (2006) An introduction to TRP channels. Annu Rev Physiol 68: 619-647.

Renkema KY, Nijenhuis T, van der Eerden BC, van der Kemp AW, Weinans $H$, van Leeuwen JP, Bindels RJ, Hoenderop JG (2005) Hypervitaminosis $\mathrm{D}$ mediates compensatory $\mathrm{Ca} 2+$ hyperabsorption in TRPV5 knockout mice. J Am Soc Nephrol 16: 31883195.

Ricciotti E, FitzGerald GA (2011) Prostaglandins and inflammation. Arterioscler Thromb Vasc Biol 31: 986-1000.

Risbud MV, Shapiro IM (2014) Role of cytokines in intervertebral disc degeneration: pain and disc content. Nat Rev Rheumatol 10: 44-56.

Roberts S, Evans H, Trivedi J, Menage J (2006) Histology and pathology of the human intervertebral disc. J Bone Joint Surg Am 88 Suppl 2: 10-14.

Rohacs T (2013) Regulation of transient receptor potential channels by the phospholipase $\mathrm{C}$ pathway. Adv Biol Regul 53: 341-355. 
Sah R, Mesirca P, Mason X, Gibson W, BatesWithers C, Van den Boogert M, Chaudhuri D, Pu WT, Mangoni ME, Clapham DE (2013) Timing of myocardial trpm7 deletion during cardiogenesis variably disrupts adult ventricular function, conduction, and repolarization. Circulation 128: 101-114.

Sanchez JC, Danks TA, Wilkins RJ (2003) Mechanisms involved in the increase in intracellular calcium following hypotonic shock in bovine articular chondrocytes. Gen Physiol Biophys 22: 487-500.

Schaible HG (2012) Mechanisms of chronic pain in osteoarthritis. Curr Rheumatol Rep 14: 549-556.

Schmidt M, Dubin AE, Petrus MJ, Earley TJ, Patapoutian A (2009) Nociceptive signals induce trafficking of TRPA1 to the plasma membrane. Neuron 64: 498-509.

Schwarzer AC, Aprill CN, Derby R, Fortin J, Kine G, Bogduk N (1995) The prevalence and clinical features of internal disc disruption in patients with chronic low back pain. Spine (Phila Pa 1976) 20: 18781883.

Setton LA, Chen J (2006) Mechanobiology of the intervertebral disc and relevance to disc degeneration. J Bone Joint Surg Am 88 Suppl 2: 52-57.

Shen B, Wong CO, Lau OC, Woo T, Bai S, Huang Y, Yao X (2015) Plasma membrane mechanical stress activates TRPC5 channels. PLoS One 10: e0122227.

Shen Y, Heimel JA, Kamermans M, Peachey NS, Gregg RG, Nawy S (2009) A transient receptor potential-like channel mediates synaptic transmission in rod bipolar cells. J Neurosci 29: 6088-6093.

Sivan SS, Wachtel E, Roughley P (2014) Structure, function, aging and turnover of aggrecan in the intervertebral disc. Biochim Biophys Acta 1840: 31813189.

So K, Haraguchi K, Asakura K, Isami K, Sakimoto S, Shirakawa H, Mori Y, Nakagawa T, Kaneko S (2015) Involvement of TRPM2 in a wide range of inflammatory and neuropathic pain mouse models. J Pharmacol Sci 127: 237-243.

Sokolove J, Lepus CM (2013) Role of inflammation in the pathogenesis of osteoarthritis: latest findings and interpretations. Ther Adv Musculoskelet Dis 5: 77-94.

Song T, Ma J, Guo L, Yang P, Zhou X, Ye T (2017) Regulation of chondrocyte functions by transient receptor potential cation channel V6 in osteoarthritis. J Cell Physiol 232: 3170-3181.

Sophia Fox AJ, Bedi A, Rodeo SA (2009) The basic science of articular cartilage: structure, composition, and function. Sports Health 1: 461-468.

Spassova MA, Hewavitharana T, Xu W, Soboloff J, Gill DL (2006) A common mechanism underlies stretch activation and receptor activation of TRPC6 channels. Proc Natl Acad Sci U S A 103: 16586-16591.

Stein AT, Ufret-Vincenty CA, Hua L, Santana LF, Gordon SE (2006) Phosphoinositide 3-kinase binds to TRPV1 and mediates NGF-stimulated TRPV1 trafficking to the plasma membrane. J Gen Physiol 128: $509-522$.
Stowers L, Holy TE, Meister M, Dulac C, Koentges G (2002) Loss of sex discrimination and male-male aggression in mice deficient for TRP2. Science 295: 1493-1500.

Strotmann R, Harteneck C, Nunnenmacher K, Schultz G, Plant TD (2000) OTRPC4, a nonselective cation channel that confers sensitivity to extracellular osmolarity. Nat Cell Biol 2: 695-702.

Strubing C, Krapivinsky G, Krapivinsky L, Clapham DE (2001) TRPC1 and TRPC5 form a novel cation channel in mammalian brain. Neuron 29: 645655.

Sullivan MN, Gonzales AL, Pires PW, Bruhl A, Leo MD, Li W, Oulidi A, Boop FA, Feng Y, Jaggar JH, Welsh DG, Earley S (2015) Localized TRPA1 channel $\mathrm{Ca} 2+$ signals stimulated by reactive oxygen species promote cerebral artery dilation. Sci Signal 8: ra2.

Sun L, Hua Y, Vergarajauregui S, Diab HI, Puertollano R (2015) Novel role of TRPML2 in the regulation of the innate immune response. J Immunol 195: 4922-4932.

Sun W, Uchida K, Suzuki Y, Zhou Y, Kim M, Takayama Y, Takahashi N, Goto T, Wakabayashi S, Kawada T, Iwata Y, Tominaga M (2016) Lack of TRPV2 impairs thermogenesis in mouse brown adipose tissue. EMBO Rep 17: 383-399.

Suzuki M, Mizuno A, Kodaira K, Imai M (2003) Impaired pressure sensation in mice lacking TRPV4. J Biol Chem 278: 22664-22668.

Suzuki Y, Kovacs CS, Takanaga H, Peng JB, Landowski CP, Hediger MA (2008) Calcium channel TRPV6 is involved in murine maternal-fetal calcium transport. J Bone Miner Res 23: 1249-1256.

Sztrolovics R, Alini M, Roughley PJ, Mort JS (1997) Aggrecan degradation in human intervertebral disc and articular cartilage. Biochem J 326: 235-241.

Tan CH, McNaughton PA (2016) The TRPM2 ion channel is required for sensitivity to warmth. Nature 536: 460-463.

Thakur M, Dickenson AH, Baron R (2014) Osteoarthritis pain: nociceptive or neuropathic?. Nat Rev Rheumatol 10: 374-380.

Tiruppathi C, Ahmmed GU, Vogel SM, Malik AB (2006) Ca2+ signaling, TRP channels, and endothelial permeability. Microcirculation 13: 693-708.

Todaka H, Taniguchi J, Satoh J, Mizuno A, Suzuki M (2004) Warm temperature-sensitive transient receptor potential vanilloid 4 (TRPV4) plays an essential role in thermal hyperalgesia. J Biol Chem 279: 35133-35138.

Tsai TT, Danielson KG, Guttapalli A, Oguz E, Albert TJ, Shapiro IM, Risbud MV (2006) TonEBP/ OREBP is a regulator of nucleus pulposus cell function and survival in the intervertebral disc. J Biol Chem 281: 25416-25424.

Tsvilovskyy VV, Zholos AV, Aberle T, Philipp SE, Dietrich A, Zhu MX, Birnbaumer L, Freichel M, Flockerzi V (2009) Deletion of TRPC4 and TRPC6 in mice impairs smooth muscle contraction and intestinal motility in vivo. Gastroenterology 137: 14151424. 
Ueno S, Nishiguchi KM, Tanioka H, Enomoto A, Yamanouchi T, Kondo M, Yasuma TR, Yasuda S, Kuno N, Takahashi M, Terasaki H (2013) Degeneration of retinal on bipolar cells induced by serum including autoantibody against TRPM1 in mouse model of paraneoplastic retinopathy. PLoS One 8: e81507.

Urban JPG, Roberts S (2003) Degeneration of the intervertebral disc. Arthritis Res Ther 5: 120-130.

Urban JPG, Smith S, Fairbank JCT (2004) Nutrition of the intervertebral disc. Spine (Phila Pa 1976) 29: 2700-2709.

van Abel M, Hoenderop JG, Bindels RJ (2005) The epithelial calcium channels TRPV5 and TRPV6: regulation and implications for disease. Naunyn Schmiedebergs Arch Pharmacol 371: 295-306.

van der Eerden BC, Koek WN, Roschger P, Zillikens MC, Waarsing JH, van der Kemp A, Schreuders-Koedam M, Fratzl-Zelman N, Leenen PJ, Hoenderop JG, Klaushofer K, Bindels RJ, van Leeuwen JP (2016) Lifelong challenge of calcium homeostasis in male mice lacking TRPV5 leads to changes in bone and calcium metabolism. Oncotarget 7: 24928-24941.

van Dijk B, Potier E, Ito K (2011) Culturing bovine nucleus pulposus explants by balancing medium osmolarity. Tissue Eng Part C Methods 17: 1089-1096.

Vazquez G, Wedel BJ, Aziz O, Trebak M, Putney JW (2004) The mammalian TRPC cation channels. Biochim Biophys Acta 1742: 21-36.

Venkatachalam K, Montell C (2007) TRP channels. Annu Rev Biochem 76: 387-417.

Venugopal B, Browning MF, Curcio-Morelli C, Varro A, Michaud N, Nanthakumar N, Walkley SU, Pickel J, Slaugenhaupt SA (2007) Neurologic, gastric, and opthalmologic pathologies in a murine model of mucolipidosis type IV. Am J Hum Genet 81: 1070 1083.

Verteramo A, Seedhom BB (2007) Effect of a single impact loading on the structure and mechanical properties of articular cartilage. J Biomech 40: 35803589.

Vo NV, Hartman RA, Patil PR, Risbud MV, Kletsas D, Iatridis JC, Hoyland JA, Le Maitre CL, Sowa GA, Kang JD (2016) Molecular mechanisms of biological aging in intervertebral discs. J Orthop Res 34: 12891306.

Vo NV, Hartman RA, Yurube T, Jacobs LJ, Sowa GA, Kang JD (2013) Expression and regulation of metalloproteinases and their inhibitors in intervertebral disc aging and degeneration. Spine J 13: 331-341.

Vriens J, Owsianik G, Hofmann T, Philipp SE, Stab J, Chen X, Benoit M, Xue F, Janssens A, Kerselaers S, Oberwinkler J, Vennekens R, Gudermann T, Nilius B, Voets T (2011) TRPM3 is a nociceptor channel involved in the detection of noxious heat. Neuron 70: 482-494.

Wakabayashi H, Wakisaka S, Hiraga T, Hata K, Nishimura R, Tominaga M, Yoneda T (2017) Decreased sensory nerve excitation and bone pain associated with mouse Lewis lung cancer in TRPV1- deficient mice. J Bone Miner Metab. DOI: 10.1007/ s00774-017-0842-7.

Walder RY, Yang B, Stokes JB, Kirby PA, Cao X, Shi P, Searby CC, Husted RF, Sheffield VC (2009) Mice defective in Trpm6 show embryonic mortality and neural tube defects. Hum Mol Genet 18: 4367-4375.

Walter BA, Purmessur D, Moon A, Occhiogrosso J, Laudier DM, Hecht AC, Iatridis JC (2016) Reduced tissue osmolarity increases Trpv4 expression and pro-inflammatory cytokines in intervertebral disc cells. Eur Cell Mater 32: 123-136.

Wang N, Chopin E, Xia Y (2013) The effects of mechanical loading and gadolinium concentration on the change of $\mathrm{T} 1$ and quantification of glycosaminoglycans in articular cartilage by microscopic MRI. Phys Med Biol 58: 4535-4547.

Wang WJ, Yu XH, Wang C, Yang W, He WS, Zhang SJ, Yan YG, Zhang J (2015) MMPs and ADAMTS in intervertebral disc degeneration. Clin Chim Acta 448: 238-246.

Weissgerber P, Kriebs U, Tsvilovskyy V, Olausson J, Kretz O, Stoerger C, Mannebach S, Wissenbach U, Vennekens R, Middendorff R, Flockerzi V, Freichel M (2012) Excision of Trpv6 gene leads to severe defects in epididymal $\mathrm{Ca} 2+$ absorption and male fertility much like single D541A pore mutation. J Biol Chem 287: 17930-17941.

Wieser S, Horisberger B, Schmidhauser S, Eisenring C, Brugger U, Ruckstuhl A, Dietrich J, Mannion AF, Elfering A, Tamcan O, Muller U (2011) Cost of low back pain in Switzerland in 2005. Eur J Health Econ 12: 455-467.

Wilusz RE, Weinberg JB, Guilak F, McNulty AL (2008) Inhibition of integrative repair of the meniscus following acute exposure to interleukin-1 in vitro. J Orthop Res 26: 504-512.

Woudenberg-Vrenken TE, Sukinta A, van der Kemp AW, Bindels RJ, Hoenderop JG (2011) Transient receptor potential melastatin 6 knockout mice are lethal whereas heterozygous deletion results in mild hypomagnesemia. Nephron Physiol 117: 11-19.

Wu D, Huang W, Richardson PM, Priestley JV, Liu M (2008) TRPC4 in rat dorsal root ganglion neurons is increased after nerve injury and is necessary for neurite outgrowth. J Biol Chem 283: 416-426.

Wu G, D'Agati V, Cai Y, Markowitz G, Park JH, Reynolds DM, Maeda Y, Le TC, Hou H, Jr., Kucherlapati R, Edelmann W, Somlo S (1998) Somatic inactivation of $\mathrm{Pkd} 2$ results in polycystic kidney disease. Cell 93: 177-188.

Wu LJ, Sweet TB, Clapham DE (2010) International union of basic and clinical pharmacology. LXXVI. Current progress in the mammalian TRP ion channel family. Pharmacol Rev 62: 381-404.

Wu Z, Autry AE, Bergan JF, Watabe-Uchida M, Dulac CG (2014) Galanin neurons in the medial preoptic area govern parental behaviour. Nature 509: 325-330.

Wuertz K, Godburn K, MacLean JJ, Barbir A, Donnelly JS, Roughley PJ, Alini M, Iatridis JC (2009) In vivo remodeling of intervertebral discs in response 
to short- and long-term dynamic compression. J Orthop Res 27: 1235-1242.

Wuertz K, Haglund L (2013) Inflammatory mediators in intervertebral disk degeneration and discogenic pain. Global Spine J 3: 175-184.

Wuertz K, Urban JP, Klasen J, Ignatius A, Wilke HJ, Claes L, Neidlinger-Wilke C (2007) Influence of extracellular osmolarity and mechanical stimulation on gene expression of intervertebral disc cells. J Orthop Res 25: 1513-1522.

Wuertz K, Vo N, Kletsas D, Boos N (2012) Inflammatory and catabolic signalling in intervertebral discs: the roles of NF-kappaB and MAP kinases. Eur Cell Mater 23: 103-120.

Xiong WH, Duvoisin RM, Adamus G, Jeffrey BG, Gellman C, Morgans CW (2013) Serum TRPM1 autoantibodies from melanoma associated retinopathy patients enter retinal on-bipolar cells and attenuate the electroretinogram in mice. PLoS One 8: e69506.

Ye M, Yang W, Ainscough JF, Hu XP, Li X, Sedo A, Zhang XH, Zhang X, Chen Z, Li XM, Beech DJ, Sivaprasadarao A, Luo JH, Jiang LH (2014) TRPM2 channel deficiency prevents delayed cytosolic Zn2+ accumulation and CA1 pyramidal neuronal death after transient global ischemia. Cell Death Dis 5: e1541.

Yin JH, Xia Y (2014) Proteoglycan concentrations in healthy and diseased articular cartilage by Fourier transform infrared imaging and principal component regression. Spectrochim Acta A Mol Biomol Spectrosc 133: 825-830.

Yu L, Yang F, Luo H, Liu FY, Han JS, Xing GG, Wan Y (2008) The role of TRPV1 in different subtypes of dorsal root ganglion neurons in rat chronic inflammatory nociception induced by complete Freund's adjuvant. MolPain 4: 61.

Yu S, Ouyang A (2009) TRPA1 in bradykinininduced mechanical hypersensitivity of vagal $C$ fibers in guinea pig esophagus. Am J Physiol Gastrointest Liver Physiol 296: G255-265.

Zhang JM, An J (2007) Cytokines, inflammation, and pain. Int Anesthesiol Clin 45: 27-37.

Zhang RX, Ren K, Dubner R (2013) Osteoarthritis pain mechanisms: basic studies in animal models. Osteoarthritis Cartilage 21: 1308-1315.

Zhang XM, Huang JH, McNaughton PA (2005) NGF rapidly increases membrane expression of TRPV1 heat-gated ion channels. EMBO J 24: 42114223.

Zhang YF, Hoon MA, Chandrashekar J, Mueller KL, Cook B, Wu DQ, Zuker CS, Ryba NJP (2003) Coding of sweet, bitter, and umami tastes: different receptor cells sharing similar signaling pathways. Cell 112: 293-301.

Zheng J (2013) Molecular mechanism of TRP channels. Compr Physiol 3: 221-242.

Zhou X, Ye Y, Sun Y, Li X, Wang W, Privratsky B, Tan S, Zhou Z, Huang C, Wei YQ, Birnbaumer L, Singh BB, Wu M (2015) Transient receptor potential channel 1 deficiency impairs host defense and proinflammatory responses to bacterial infection by regulating protein kinase $\mathrm{C} \alpha$ signaling. Mol Cell Biol 35: 2729-2739.

Zhou YL, David MA, Chen XY, Wan LQ, Duncan RL, Wang LY, Lu XL (2016) Effects of osmolarity on the spontaneous calcium signaling of in situ juvenile and adult articular chondrocytes. Ann Biomed Eng 44: 1138-1147.

Zimmermann K, Lennerz JK, Hein A, Link AS, Kaczmarek JS, Delling M, Uysal S, Pfeifer JD, Riccio A, Clapham DE (2011) Transient receptor potential cation channel, subfamily C, member 5 (TRPC5) is a cold-transducer in the peripheral nervous system. Proc Natl Acad Sci U S A 108: 18114-18119.

Zvick J (2017) The role of TRP channels in inflammation of intervertebral discs. Master Thesis, Archive of Department of Health Sciences and Technology, ETH Zurich, Hoenggerbergring 64, 8093 Zurich, Switzerland.

\section{Web References}

1. http://www.oarsijournal.com/article/S10634584(16)00317-4/fulltext

2. http://acrabstracts.org/abstract/the-role-oftrpc6-in-cxcr2-mediated-chondrocyte-phenotypicstability/

\section{Discussion with Reviewers}

Zhen Li: According to Birnbaumer (2009), most KO phenotypes are quite moderate, suggesting that TRP isoforms are able to compensate for the lack of a specific channel. This suggests that none of the TRP member is specifically related to a certain function and would make it extremely difficult to use TRP channels as therapeutic targets. What has been done or can be done in the future to solve this issue?

Author: The main challenge in using TRP channels as therapeutic targets is, indeed, their versatility and diverse (possibly tissue-specific) functionality. These features may allow TRP channels to compensate for each other's function, resulting in moderate phenotypes in TRP KO mice. Although most mouse TRP KO phenotypes are not lethal, they are associated with certain pathologies. For example, the genetic $\mathrm{KO}$ of TRPV4 results in the development of OA and the $\mathrm{KO}$ of TRPA1 decreases hypersensitivity and inflammatory responses (Horváth et al., 2016; O'Conor et al., 2013). Chemical activation of these channels leads to opposite effects (McNulty et al., 2015), suggesting specific relationship between these channels and particular pathologies, as well as, possibility for therapeutic targeting.

Versatility of some TRP channels may, indeed, reduce the efficiency of TRP-specific drugs or generate unwanted adverse effects. For example, therapeutic targeting of a single member of the TRPC family can disturb the balance among several 
TRPC members, which is likely more important than complete inhibition or activation of one TRPC channel. This challenge may be overcome by using specific combinations of TRP channel agonists and antagonists, smart drug delivery systems, providing their sustained release in a particular cell type, environmentally-responsive systems (e.g. drug release upon reduced osmolarity) or targeted genome editing techniques.

Currently, the understanding of which TRP channels are important for signaling in chondrocytes and what TRP-related mechanisms are altered in joint diseases is not complete. Upon uncovering the exact role of TRP channels in cartilage and IVD, it will be possible to assess confidently their potential therapeutic significance.

Zhen Li: Compared to other potential targets, do you consider TRP channels as more promising therapeutic targets for pain alleviation in joint disease and disc degenerative disease?
Authors: It is possible. One hypothesis can be that certain TRP channels, for example TRPA1 and TRPV1, are (over)expressed both in sensory neurons and chondrocytes/IVD cells, with presumably different functions. We hypothesised that inhibition of these overexpressed or overactivated TRP channels on neurons would alleviate pain, whereas their inhibition in chondrocytes/IVD cells might have different effects, for example reduced inflammation and slower degeneration. Furthermore, one can speculate that the inhibition of a cell receptor can be easier and more specific than the inhibition of all possible activators of this receptor. As an example, antagonising the receptor for IL-1 $\beta$ in cartilaginous tissues can be more promising and less time consuming than developing inhibitors for all known activators of IL-1 $\beta$-regulated pathways.

Editor note: The scientific editor for this paper was Mauro Alini. 